\title{
14. PHASE CHEMISTRY, FRACTIONAL CRYSTALLIZATION, AND MAGMA MIXING IN BASALTS FROM THE GULF OF CALIFORNIA, DEEP SEA DRILLING PROJECT LEG $64^{1}$
}

\author{
Michael R. Perfit, Research School of Earth Sciences, Australian National University, Canberra, 2600, Australia, \\ Andrew D. Saunders, Department of Geology, Bedford College, Regent's Park, London NW1 4NS, United Kingdom, \\ and \\ Daniel J. Fornari, Department of Geological Sciences, State University of New York at Albany, Albany, New York
}

\begin{abstract}
Major-element, trace-element, and mineralogic data from basalts drilled during Leg 64 indicate that a wide spectrum of N-type MORB have been erupted in the Gulf of California. Leg 64 basalts have chemical and mineralogical characteristics broadly similar to those from the East Pacific Rise and Nazca Plate. They are not nearly so evolved as basaltic lavas recovered from the Galapagos Spreading Center. Trace-element data suggest that several N-type mantle sources or a spatially heterogeneous mantle were partially melted to generate the spectrum of basalts recovered during Leg 64 . However, simple, closed-system crystal fractionation does not adequately explain all of the observed chemical and mineralogical features. Mixing of primitive magmas, with observed An-rich plagioclase xenocrysts and fractionating magmatic liquids, is a plausible mechanism which can help to explain the evolution of basaltic magmas in the Gulf of California.
\end{abstract}

\section{INTRODUCTION}

Basalt was cored in Holes 474A, 475B, 477, 477A, 478, and 481A during Leg 64 of the Deep Sea Drilling Project (DSDP). Hole 474A is off the southern end of Baja California on oceanic crust west of the East Pacific Rise. In this hole, drilling penetrated three dolerite sills before encountering a pillow basalt/sill sequence believed to be Oceanic Layer 2. Basalt cobbles were recovered from Hole 475B (located within a slope basin 21 $\mathrm{km}$ southeast of Baja), but these are not considered part of an in situ flow. Holes 477 and 481 are on the southern and northern rifts, respectively, of the Guaymas Basin and are part of the actively spreading oceanic crust extending from the East Pacific Rise to the San Andreas Fault. At both sites, Quaternary sediments have been intruded by basalt, dolerite, and gabbro sills. Hole 478 was drilled in young oceanic crust $12 \mathrm{~km}$ northwest of the active rift; drilling penetrated a sequence similar to the sills intruding turbidites in Holes 477 and 481 .

The range of compositions of the major mineral phases in representative samples from Holes 474A, 475B, 477, and 478 have been determined. Petrographic descriptions of the samples are presented in Table 1 . Major-element analyses and selected elemental ratios of these samples are presented in Table 2. Detailed accounts of the whole-rock major- and trace-element data are presented in Saunders et al. and Fornari et al. (both papers this volume, Pt. 2, hereafter cited "this volume"). Where a specific whole-rock composition was not measured, the chemical analysis for the nearest sample in the core and unit is presented in Table 2.

We have used the combined petrologic and chemical data to investigate the intra- and intersite relations

\footnotetext{
${ }^{1}$ Curray, J. R., Moore, D. G., et al., Init. Repts. DSDP, 64: Washington (U.S. Govt. Printing Office)
}

among the variety of basalts recovered during Leg 64 . In particular, we have tested the hypothesis that fractional crystallization may have played an important role in generating the range of basalt compositions. In light of the tectonic setting of these holes, it is important to see if there are any petrographic or chemical characteristics that distinguish these basalts from other Pacific midocean ridge basalts (MORB).

\section{MAJOR-ELEMENT VARIATIONS}

Complete listings of the major-element compositions of crystalline and glassy basalts are presented in Saunders et al. (this volume) and Fornari et al. (this volume). Only the composition of samples selected for microprobe analysis and representative samples used in fractionation calculations is presented in Table 2 . In general, the samples span the entire compositional range of basalts recovered during Leg 64 . The basalts range from slightly nepheline normative (Hole 475B) to slightly quartz normative (Hole 474) tholeiites; the majority are subalkaline tholeiites.

Nearly all of the samples plot in the fields defined by Bence et al. (1979) for MORB from the major ocean basins (Figs. 1 and 2). As a whole, the Leg 64 basalts exhibit quite a large degree of chemical diversity and differentiation. For example, $\mathrm{Mg}$ numbers $\left(\mathrm{Mg} / \mathrm{Mg}+\mathrm{Fe}^{2+}\right.$ $\times 100$ ) vary from $\sim 75$ in picritic basalt to $<55$ in the most fractionated samples (Fig. 3). In detail, basalts from Hole 474 exhibit the greatest variation in $\mathrm{Mg}$ number $(61.5 \pm 5.0)$ when compared to basalt suites from the other holes, which have more restricted $\mathrm{Mg}$ numbers: e.g., Holes $475 \mathrm{~B}(66.9 \pm 2.4), 477(65.5 \pm 3.1)$, $477 \mathrm{~A}(60.3 \pm 1.4), 478(67.1 \pm 2.6)$, and $481 \mathrm{~A}(59.5 \pm$ 2.6). These averages are relatively high, considering that the average $\mathrm{Mg}$ number for $600 \mathrm{MORB}$ basalt glasses is 58.6 (Wilkinson, in press) and $58.8 \pm 2.9$ for 14 Leg 64 glasses analyzed by Fornari et al. (this volume). 
Table 1. Brief petrographic descriptions of analyzed samples.

\begin{tabular}{|c|c|}
\hline $\begin{array}{l}\text { Sample } \\
\text { (interval in } \mathrm{cm} \text { ) }\end{array}$ & Description \\
\hline $\begin{array}{r}474 \mathrm{~A}-40-2 \\
38-40(38)\end{array}$ & $\begin{array}{l}\text { Olivine-rich dolerite: No primary phenocrysts, but sample contains as much as } \\
30 \% \text { pseudomorphs of olivine }(0.3-3.0 \mathrm{~mm}) \text {. Groundmass contains plagioclase } \\
(0.3-0.8 \mathrm{~mm})(30 \%) \text {; anhedral, interstitial clinopyroxene }(0.3-0.8 \mathrm{~mm})(30 \%) \text {; } \\
\text { altered olivine }(0.3-0.6 \mathrm{~mm})(10 \%) \text {; magnetite }(5 \%) \text {; subophitic texture. }\end{array}$ \\
\hline $\begin{array}{l}474 \mathrm{~A}-42-2 \\
20-23\end{array}$ & $\begin{array}{l}\text { Dolerite: equigranular with some altered olivine phenocrysts and moderate altera- } \\
\text { tion; minor phenocrysts of plagioclase and spinel with interstitial clino-- } \\
\text { pyroxene. }\end{array}$ \\
\hline $\begin{array}{l}474 \mathrm{~A}-45-4, \\
7-9(10)\end{array}$ & $\begin{array}{l}\text { Dolerite: subophitic to hyalophitic, containing laths of plagioclase }(0.5-2.0 \mathrm{~mm}) \\
\text { surrounding altered olivine and fresh clinopyroxene phenocrysts }(0.25-1.0 \mathrm{~mm}) \\
\text { in a matrix of plagioclase, clinopyroxene, and glass with abundant } \\
\text { titanomagnetite grains. }\end{array}$ \\
\hline $\begin{array}{l}474 \mathrm{~A}-46-3, \\
80-82\end{array}$ & $\begin{array}{l}\text { Basalt: porphyritic with large plagioclase megacrysts (as long as } 1 \mathrm{~cm} \text { ) set in a fine } \\
\text { matrix of plagioclase olivine, clinopyroxene, and fine opaques. }\end{array}$ \\
\hline $\begin{array}{l}474 \mathrm{~A}-49-3 \\
146-149\end{array}$ & $\begin{array}{l}\text { Pillow basalt: plagioclase phyric, megacryst-rich, with megacrysts as long as } 1.5 \\
\mathrm{~cm} \text { in some sections; microphenocrysts of plagioclase (10\%), olivine (5\%), and } \\
\text { spinel (occasionally clinopyroxene) in an aphanitic matrix with quench tex- } \\
\text { tures. }\end{array}$ \\
\hline $\begin{array}{l}475 \mathrm{~B}-2-1, \\
0-9(14)\end{array}$ & $\begin{array}{l}\text { Olivine basalt: porphyritic with a quenched, variolitic and intersertal texture; } \\
\text { anhedral to subhedral olivine phenocrysts }(0.2-2.0 \text { mm) }(10 \%) \text {; no plagioclase } \\
\text { phenocrysts; skeletal, elongate olivine microlites }(-5 \%) \text { and plagioclase } \\
\text { microlites }(50 \%) \text { in the groundmass; some in variolitic clusters; approximately } \\
20 \% \text { clinopyroxene and } 10 \% \text { iron-titanium oxides lie in about } 10 \% \text { meso- } \\
\text { stasis. }\end{array}$ \\
\hline $\begin{array}{l}477-13-2 \\
145-146(85)\end{array}$ & $\begin{array}{l}\text { Plagioclase-phyric dolerite: subophitic to intergranular with plagioclase } \\
\text { phenocrysts (as long as } 4 \mathrm{~mm})(15 \%) \text { surrounded by smaller plagioclase laths } \\
\text { enclosing or partially enclosing anhedral to subhedral grains of clinopyroxene } \\
\text { (10\%) and olivine }(15 \%) ; \text { groundmass is composed of plagioclase microlites } \\
(-30 \%) \text {, olivine }(-10 \%) \text {, clinopyroxene }(-10 \%) \text {, magnetite }(-5 \%) \text {, and } \\
\text { some olivine. }\end{array}$ \\
\hline $\begin{array}{l}478-42-2, \\
82-83(85)\end{array}$ & $\begin{array}{l}\text { Dolerite: contains large }(1-4 \mathrm{~mm}) \text { clinopyroxene phenocrysts ophitically enclosing } \\
\text { smaller plagioclase }(1 \mathrm{~mm}) \text { laths. Matrix is composed of plagioclase }(25 \%) \text {, } \\
\text { anhedral, clinopyroxene, olivine and iron-titanium oxides }(\sim 20 \%) \text {. }\end{array}$ \\
\hline $\begin{array}{l}478-51-3, \\
52-53(48,111)\end{array}$ & $\begin{array}{l}\text { Dolerite with gabbro xenoliths: inequigranular ophitic, with large clinopyroxene } \\
\text { (1-6 mm) enclosing plagioclase }(0.5-1.5 \mathrm{~mm} \text { ) laths and olivine micro- } \\
\text { phenocrysts; approximately } 50 \% \text { plagioclase, } 30 \% \text { clinopyroxene, } 10 \% \text { olivine, } \\
5 \% \text { iron-titanium oxides. }\end{array}$ \\
\hline
\end{tabular}

Note: The petrographic descriptions are generalized and based on observations made from our own probed sections and thin sections prepared during the cruise. Where petrographic data were used from core intervals other than those of the probed section, the level (in $\mathrm{cm}$ ) is given in parentheses.

Within each site, the major-element variations occurring with decreasing $\mathrm{Mg}$ number define trends on variation diagrams that may be interpreted as a consequence of fractional crystallization. For example, increases in $\mathrm{Al}_{2} \mathrm{O}_{3}$ with decreasing $\mathrm{MgO}$ (Fig. 1) in basalts from Holes 477A, 478, and the more mafic members of 474A may result from the removal of olivine $(\mathrm{Ol})$, clinopyroxene ( $\mathrm{Cpx})$, or $\mathrm{Ol}+\mathrm{Cpx}$ from a magma. Conversely, decreases in $\mathrm{Al}_{2} \mathrm{O}_{3}$ with decreasing $\mathrm{MgO}$, as observed in Holes $474 \mathrm{~A}$ and $481 \mathrm{~A}$, may be caused by plagioclasedominated crystal fractionation. Major-element trends in MORB glasses clearly show the effects of plagioclase (Plag) + Ol fractionation (Fig. 1). A continual enrich- ment of $\mathrm{TiO}_{2}$ with decreasing $\mathrm{Mg}$ number in the Leg 64 basalts is evident (Fig. 2) and is a common feature in most MORB suites. Since Ti is an incompatible element in the major liquidus phases in MORB, the continual enrichment could reflect any combination of Plag, Ol, and $\mathrm{Cpx}$ fractionation. Highly evolved FeTi basalts, such as those sampled along the Galapagos Rift (Byerly, 1980; Perfit et al., 1980), are absent from the Leg 64 suites.

The effects of fractional crystallization (or crystal accumulation) are more clearly defined by $\mathrm{CaO} / \mathrm{Al}_{2} \mathrm{O}_{3}$ ratios versus $\mathrm{Mg}$-number variation (Table 2, Fig. 3 ). In general, there is a gradual increase in the $\mathrm{CaO} / \mathrm{Al}_{2} \mathrm{O}_{3}$

Table 2. Selected major-element compositions of basalts used in fractionation calculations, Leg $64 .^{\mathrm{a}}$

\begin{tabular}{|c|c|c|c|c|c|c|c|c|c|c|c|c|c|c|c|c|c|c|}
\hline \multirow{2}{*}{$\begin{array}{l}\text { Hole } \\
\text { Core/Section } \\
\text { Level }(\mathrm{cm})\end{array}$} & \multicolumn{11}{|c|}{$474 \mathrm{~A}$} & \multicolumn{7}{|c|}{ 475B } \\
\hline & $\begin{array}{c}42-1 \\
6\end{array}$ & $\begin{array}{c}40-1 \\
19\end{array}$ & $\begin{array}{c}40-2 \\
40\end{array}$ & $\begin{array}{c}39-3 \\
148\end{array}$ & $\begin{array}{c}43-1 \\
119\end{array}$ & $\begin{array}{c}45-4 \\
64\end{array}$ & $\begin{array}{c}46-3 \\
74\end{array}$ & $\begin{array}{l}46-2 \\
112\end{array}$ & $\begin{array}{c}49-1 \\
2\end{array}$ & $\begin{array}{c}49-2 \\
31\end{array}$ & $\begin{array}{l}47-1 \\
127 \\
\end{array}$ & $\begin{array}{c}48-1 \\
101 \\
\end{array}$ & $\begin{array}{c}50-3 \\
91\end{array}$ & $\begin{array}{c}50-4 \\
1\end{array}$ & $\begin{array}{l}49-3 \\
133\end{array}$ & $\begin{array}{c}4-1 \\
2\end{array}$ & $\begin{array}{c}3-1 \\
2\end{array}$ & $\begin{array}{l}2-1 \\
32^{\mathrm{a}}\end{array}$ \\
\hline Unit & 2 & 1 & 1 & 1 & 3 & 6 & 7 & $7^{b}$ & $7^{b}$ & $7^{b}$ & 7 & 7 & 8 & 8 & & & & \\
\hline $\mathrm{SiO}_{2}$ & 44.5 & 44.8 & 48.1 & 48.2 & 49.1 & 49.2 & 48.0 & 49.06 & 50.27 & 49.68 & 49.0 & 48.3 & 49.3 & 48.7 & 48.4 & 46.8 & 47.2 & 48.06 \\
\hline $\mathrm{TiO}_{2}$ & 1.28 & 1.54 & 1.59 & 1.78 & 1.97 & 1.83 & 1.37 & 1.70 & 2.15 & 2.35 & 1.40 & 1.59 & 2.25 & 2.27 & 2.04 & 1.27 & 1.33 & 1.47 \\
\hline $\mathrm{Al}_{2} \mathrm{O}_{3}$ & 15.2 & 14.7 & 14.1 & 15.6 & 15.1 & 16.2 & 17.0 & 16.62 & 16.10 & 14.94 & 17.3 & 16.4 & 15.2 & 15.2 & 16.1 & 16.2 & 16.6 & 18.01 \\
\hline $\mathrm{FeO}^{f}$ & 9.68 & 10.01 & 9.22 & 10.03 & 9.52 & 9.74 & 8.81 & 10.11 & 10.46 & 11.68 & 8.56 & 9.55 & 10.75 & 10.50 & 10.45 & 9.28 & 9.38 & 9.22 \\
\hline $\mathrm{MnO}$ & 0.17 & 0.16 & 0.17 & 0.21 & 0.17 & 0.14 & 0.16 & 0.20 & 0.20 & 0.16 & 0.16 & 0.17 & 0.17 & 0.16 & 0.21 & 0.21 & 0.14 & 0.17 \\
\hline $\mathrm{MgO}$ & 14.87 & 14.90 & 11.17 & 7.07 & 8.09 & 6.50 & 7.60 & 7.86 & 6.60 & 6.85 & 7.50 & 7.50 & 6.70 & 7.25 & 6.90 & 10.68 & 8.66 & 8.40 \\
\hline $\mathrm{CaO}$ & 9.59 & 9.27 & 10.21 & 11.17 & 11.56 & 11.53 & 12.39 & 11.21 & 10.25 & 10.90 & 12.16 & 12.31 & 10.85 & 10.84 & 11.70 & 11.48 & 11.56 & 11.36 \\
\hline $\mathrm{Na}_{2} \mathrm{O}$ & 2.47 & 2.37 & 2.66 & 3.01 & 2.62 & 2.77 & 2.34 & 2.63 & 2.88 & 2.67 & 2.44 & 2.42 & 2.82 & 2.80 & 2.71 & 2.76 & 2.90 & 3.00 \\
\hline $\mathrm{K}_{2} \mathrm{O}$ & 0.00 & 0.03 & 0.06 & 0.05 & 0.07 & 0.12 & 0.09 & 0.23 & 0.25 & 0.32 & 0.08 & 0.11 & 0.14 & 0.23 & 0.15 & 0.12 & 0.17 & 0.14 \\
\hline $\mathrm{P}_{2} \mathrm{O}_{5}$ & 0.09 & 0.13 & 0.12 & 0.12 & 0.19 & 0.20 & 0.09 & 0.11 & 0.14 & 0.22 & 0.12 & 0.10 & 0.23 & 0.26 & 0.16 & 0.08 & 0.09 & 0.07 \\
\hline LOI & 1.22 & 0.90 & 1.18 & 1.20 & 0.68 & 0.53 & 0.00 & - & - & - & 0.00 & 0.00 & 0.21 & 0.50 & 0.00 & 0.00 & 1.26 & - \\
\hline Total & 100.07 & 99.89 & 99.63 & 99.64 & 100.20 & 99.79 & 98.88 & 99.84 & 99.38 & 99.93 & 99.62 & 99.45 & 99.93 & 99.91 & 99.95 & 99.88 & 100.32 & 99.99 \\
\hline $\begin{array}{l}\mathrm{Mg} \mathrm{Number} \\
\mathrm{CaO} / \mathrm{Al}_{2} \mathrm{O}_{3}\end{array}$ & $\begin{array}{l}75.3 \\
0.631\end{array}$ & $\begin{array}{l}74.7 \\
0.631\end{array}$ & $\begin{array}{l}70.6 \\
0.724\end{array}$ & $\begin{array}{l}58.3 \\
0.716\end{array}$ & $\begin{array}{l}62.8 \\
0.766\end{array}$ & $\begin{array}{l}56.9 \\
0.712\end{array}$ & $\begin{array}{l}63.1 \\
0.729\end{array}$ & $\begin{array}{l}60.4 \\
0.674\end{array}$ & $\begin{array}{l}55.3 \\
0.637\end{array}$ & $\begin{array}{l}53.5 \\
0.730\end{array}$ & $\begin{array}{l}63.4 \\
0.703\end{array}$ & $\begin{array}{l}60.9 \\
0.751\end{array}$ & $\begin{array}{l}55.0 \\
0.714\end{array}$ & $\begin{array}{l}57.8 \\
0.713\end{array}$ & $\begin{array}{l}56.7 \\
0.727\end{array}$ & $\begin{array}{l}69.5 \\
0.709\end{array}$ & $\begin{array}{l}64.6 \\
0.696\end{array}$ & $\begin{array}{l}64.1 \\
0.631\end{array}$ \\
\hline
\end{tabular}

Note: $\mathrm{FeO}^{+}=$total $\mathrm{Fe}$ calculated as $\mathrm{Fe}^{2+} ; \mathrm{Mg}$ number $=$ atomic $\left(\mathrm{Mg} / \mathrm{Mg}+\mathrm{Fe}^{2+}\right) \times 100$, where $\mathrm{FeO} / \mathrm{FeO}+\mathrm{Fe}_{2} \mathrm{O}_{3}=0.9$.

a Data from Saunders et al. (this volume).

b Natural-glass data from Fornari et al. (this volume). 
ratio with diminishing $\mathrm{Mg}$ number within the Leg 64 basalts. This suggests that the removal of $\mathrm{Ol}+\mathrm{Plag}$ dominated the evolutionary trends in residual liquids, as Saunders et al. (this volume) have suggested. In detail, however, decreases in $\mathrm{CaO} / \mathrm{Al}_{2} \mathrm{O}_{3}$ ratios occur within individual holes (e.g., Holes 477A, 481A). This can only be a result of $\mathrm{Cpx}$-dominated fractionation, since $\mathrm{Cpx}$ has much higher $\mathrm{CaO} / \mathrm{Al}_{2} \mathrm{O}_{3}$ ratios $(\sim 4)$ than any MORB magma. In certain cases, the accumulation of plagioclase $\left(\mathrm{CaO} / \mathrm{Al}_{2} \mathrm{O}_{3}<0.54\right)$ also lowers the $\mathrm{CaO} /$ $\mathrm{Al}_{2} \mathrm{O}_{3}$ ratios of the samples. The fractionation is complex, and a single mechanism or assemblage probably cannot relate all of the recovered basalts to each other.

On the basis of trace-element abundances and ratios, Saunders et al. (this volume) have shown that basalts from Leg 64 are chemically similar to N-type MORB, but that at least two different mantle sources may have been involved in generating the chemical differences between samples from the Guaymas Basin and Holes 474 and 475. In fact, there is some evidence suggesting that chemical differences between units in one hole could also reflect chemically distinct parental magmas. Significant differences in major-element abundances of relatively primitive basalts support the concept of multiple sources. For example, relatively unfractionated basalts from Hole 478, with $\mathrm{Mg}$ numbers between 69 and 70 , have $\mathrm{CaO} / \mathrm{Al}_{2} \mathrm{O}_{3}$ ratios ranging from $\sim 0.67$ to 0.73 and $\mathrm{TiO}_{2}$ contents from 0.79 to $1.25 \mathrm{wt} . \%$. Assuming basalts with $\mathrm{Mg}$ numbers $\sim 70$ could be primary melts or derivatives obtained after some olivine fractionation, then the wide variations in chemistry may result from differing degrees of partial melting of a mantle source or melting from chemically distinct source regions.

Before assessing possible differences in melting history and mantle chemistry it is important to place constraints on the role and degree of fractional crystallization and magma mixing in this complex region. The fractionation models are used to test and quantify the hypotheses proposed by Saunders et al. (this volume), which are based on trace-element variations. Trace-element abundance modelling, constrained by the most successful major-element calculations, provides more rigorous tests of the applicability of crystal fractionation and magma mixing-but this will be presented in detail elsewhere.

\section{PHASE CHEMISTRY}

Mineral analyses were done at the University of Cambridge on an energy dispersive spectrometer (EDS) electron microprobe. Measurement and processing of peaks were done by iterative peak stripping (Statham, 1976) and correction methods are after Sweatman and Long (1969). Typical limits of detection are $\mathrm{Na} \sim 0.25 \%, \mathrm{Mg}$ $\sim 0.16 \%, \mathrm{Al}$ and $\mathrm{Si} \sim 0.10 \%$, and $\mathrm{K} \sim 0.05 \%$. Data are tabulated in Tables 3 (plagioclase), 4 (clinopyroxene), 5 (olivine), 6 (iron-titanium oxides) and 7 (spinel).

The samples for microprobe work varied from glassy, phyric basalts to aphyric, coarsely crystalline basalts and dolerites with ophitic textures. As a consequence of relatively rapid cooling, minerals in the glassy basalts show limited degrees of solid solution when compared to minerals in coarser, more crystalline dolerites.

Olivines show the most restricted range of compositional zoning and generally occur as near-liquidus phenocrysts. Olivine relicts occur in many samples, but they have been altered and pseudomorphed by clay minerals, making them unsuitable for analysis. Clinopyroxene occurs as subophitic intergrowths with plagioclase, a common groundmass phase, and rarely as poikilitic crystals or phenocrysts. Plagioclase is a ubiquitous phenocryst and groundmass phase. Plagioclase phenocrysts exhibit optical zonations, and megacrysts are commonly rounded and partially resorbed. Some of these megacrysts appear to be xenocrysts. Microphenocrysts of $\mathrm{Cr}-\mathrm{Al}$ spinel are rarely present in mafic basalts or enclosed in olivine phenocrysts; they generally contribute $>2 \%$ of the mode. Titanomagnetite is an abundant groundmass phase and, in some samples coexists with less abundant ilmenite.

\section{Plagioclase}

Plagioclase crystals generally have normal chemical zonations with calcic cores $\left(\mathrm{An}_{82-70}\right)$ and more sodic rims $\left(\mathrm{An}_{70-50}\right)$ (Fig. 4). Groundmass plagioclases tend to be more sodic (as low as $\mathrm{An}_{40}$ ) but can be as calcic $\left(\mathrm{An}_{70-75}\right)$ as larger phenocrysts. Plagioclase megacrysts

Table 2. (Continued).

\begin{tabular}{|c|c|c|c|c|c|c|c|c|c|c|c|c|c|c|c|c|c|}
\hline \multicolumn{4}{|c|}{477} & \multicolumn{4}{|c|}{$477 \mathrm{~A}$} & \multicolumn{6}{|c|}{478} & \multicolumn{4}{|c|}{$481 \mathrm{~A}$} \\
\hline $\begin{array}{c}9-1 \\
7\end{array}$ & $\begin{array}{c}11-2 \\
61\end{array}$ & $\begin{array}{c}12-4 \\
76\end{array}$ & $\begin{array}{l}13-2 \\
146\end{array}$ & $\begin{array}{c}2-1 \\
7\end{array}$ & $\begin{array}{c}2-2 \\
64\end{array}$ & $\begin{array}{l}3-1 \\
86\end{array}$ & $\begin{array}{l}3-2 \\
17\end{array}$ & $\begin{array}{c}42-2 \\
80\end{array}$ & $\begin{array}{l}43-2 \\
104\end{array}$ & $\begin{array}{c}49-1 \\
63\end{array}$ & $\begin{array}{c}51-3 \\
49\end{array}$ & $\begin{array}{c}54-1 \\
77\end{array}$ & $\begin{array}{c}54-4 \\
2\end{array}$ & $\begin{array}{c}15-3 \\
27\end{array}$ & $\begin{array}{l}15-3 \\
115\end{array}$ & $\begin{array}{l}16-2 \\
111\end{array}$ & $\begin{array}{c}17-2 \\
6\end{array}$ \\
\hline $2 \mathrm{~b}$ & $2 c$ & $2 c$ & $2 c$ & 2 & 2 & 2 & 2 & 4 & 4 & 4 & 4 & 5 & 6 & 1 & 1 & 1 & 1 \\
\hline 49.8 & 48.3 & 48.1 & 48.7 & 47.7 & 48.5 & 48.2 & 49.1 & 47.7 & 49.0 & 47.5 & 52.0 & 49.2 & 49.3 & 50.1 & 50.0 & 49.8 & 49.4 \\
\hline 1.92 & 1.17 & 1.48 & 1.58 & 1.59 & 1.76 & 1.14 & 1.53 & 0.79 & 1.68 & 0.94 & 2.13 & 1.25 & 1.90 & 2.25 & 2.14 & 1.95 & 1.98 \\
\hline 15.7 & 17.2 & 16.2 & 17.9 & 17.3 & 17.4 & 18.9 & 18.9 & 16.4 & 15.8 & 17.1 & 16.6 & 15.5 & 13.1 & 15.4 & 15.6 & 15.3 & 15.2 \\
\hline 9.22 & 8.40 & 8.97 & 8.39 & 8.57 & 8.69 & 7.27 & 7.96 & 7.87 & 8.95 & 7.74 & 7.13 & 8.30 & 9.63 & 9.79 & 9.81 & 9.00 & 9.35 \\
\hline 0.17 & 0.14 & 0.16 & 0.14 & 0.15 & 0.15 & 0.13 & 0.14 & 0.14 & 0.14 & 0.13 & 0.13 & 0.14 & 0.25 & 0.17 & 0.18 & 0.15 & 0.15 \\
\hline 6.95 & 9.20 & 9.75 & 6.65 & 8.65 & 7.23 & 7.31 & 6.02 & 8.80 & 8.60 & 8.90 & 4.13 & 9.30 & 9.00 & 6.82 & 6.25 & 7.65 & 8.05 \\
\hline 11.70 & 11.61 & 10.87 & 11.89 & 12.04 & 11.81 & 12.81 & 12.14 & 10.34 & 11.02 & 11.17 & 11.20 & 11.26 & 11.25 & 9.90 & 9.81 & 10.73 & 10.56 \\
\hline 3.11 & 2.79 & 2.76 & 3.05 & 2.91 & 3.10 & 2.82 & 2.98 & $\begin{array}{r}3.02 \\
.02\end{array}$ & $\begin{array}{r}11.82 \\
2.89\end{array}$ & 2.65 & 3.29 & $\begin{array}{r}2.47 \\
\end{array}$ & 2.62 & 3.22 & 3.14 & 2.87 & 2.68 \\
\hline 0.20 & 0.18 & 0.23 & 0.20 & 0.14 & 0.25 & 0.12 & 0.22 & 0.31 & 0.15 & 0.18 & 0.89 & 0.15 & 0.11 & 0.51 & 0.59 & 0.14 & 0.16 \\
\hline 0.33 & 0.24 & 0.25 & 0.21 & 0.14 & 0.23 & 0.12 & 0.19 & 0.18 & 0.21 & 0.15 & 0.52 & 0.19 & 0.25 & 0.34 & 0.45 & 0.32 & 0.29 \\
\hline 0.00 & 0.14 & 0.33 & 0.00 & 0.00 & 0.00 & 0.12 & 0.00 & 3.74 & 0.00 & 2.31 & 1.54 & 1.04 & 1.72 & 0.00 & 0.00 & 0.95 & 1.00 \\
\hline 100.13 & 100.28 & 100.10 & 99.64 & 100.21 & 100.08 & 99.70 & 100.16 & 100.17 & 99.46 & 99.73 & 100.28 & 99.77 & 100.16 & 100.04 & 99.11 & 99.86 & 99.85 \\
\hline $\begin{array}{l}59.9 \\
0.745\end{array}$ & $\begin{array}{l}68.5 \\
0.675\end{array}$ & 68.3 & 61,1 & $\begin{array}{l}66.7 \\
0.696\end{array}$ & 62.2 & 66.6 & 60.0 & 68.9 & 65.6 & 69.5 & 53.5 & 69.0 & 65.0 & $\begin{array}{l}57.9 \\
0.643\end{array}$ & 55.7 & $\begin{array}{c}62.8 \\
0.701\end{array}$ & 63.1 \\
\hline 0.745 & 0.675 & 0.671 & 0.664 & 0.696 & 0.679 & 0.678 & 0.642 & 0.630 & 0.697 & 0.653 & 0.675 & 0.726 & 0.859 & 0.643 & 0.629 & 0.701 & 0.695 \\
\hline
\end{tabular}




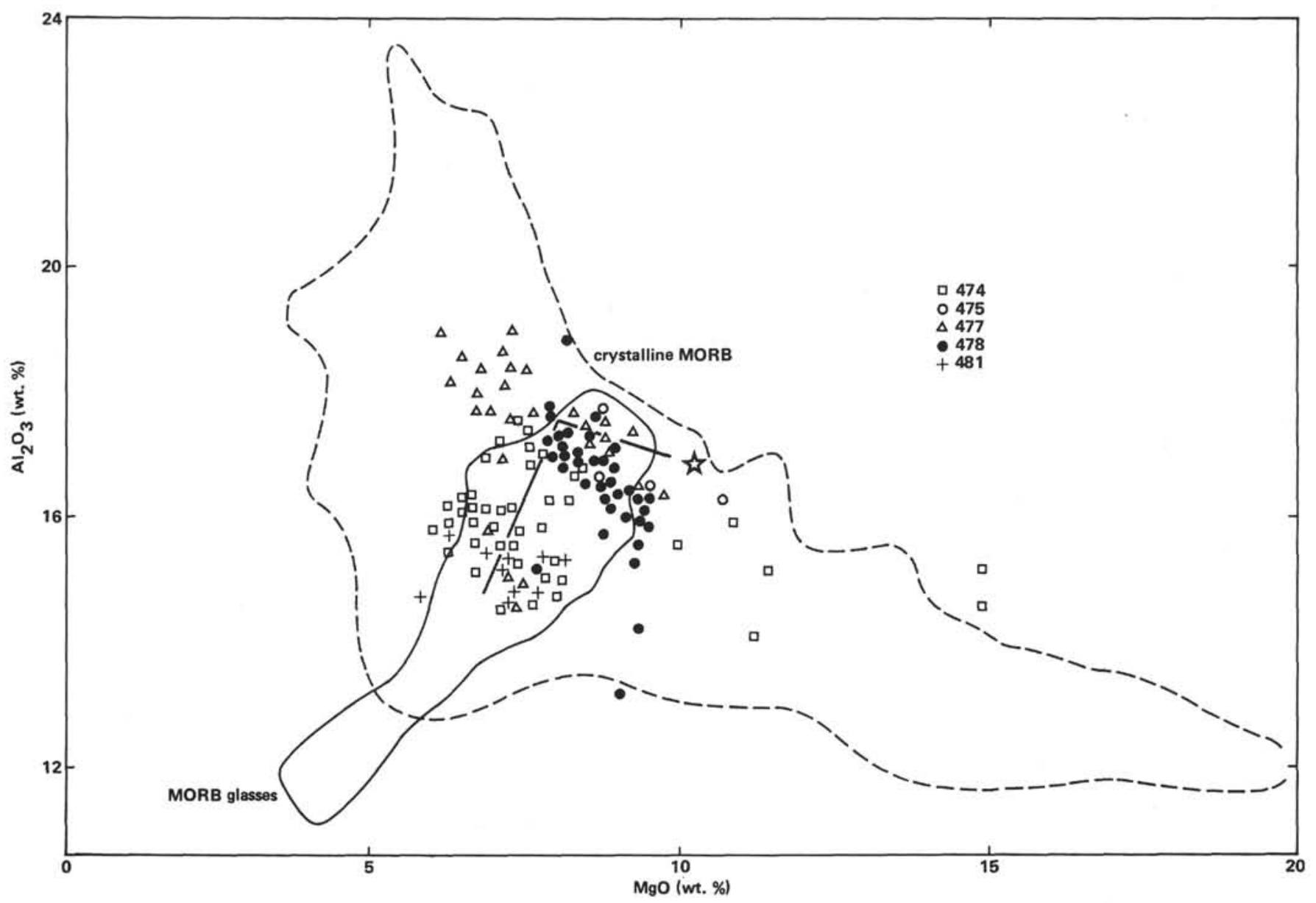

Figure 1. Variation in $\mathrm{Al}_{2} \mathrm{O}_{3}$ versus $\mathrm{MgO}$, Leg 64 basalts. (Data from Saunders et al., this volume; Fornari et al., this volume.) Fields for $\sim 1100$ ocean-floor basalt glasses [MORB glasses] and $\sim 1300$ crystalline ocean floor basalts [MORB] from Bence et al. [1979] are shown for comparison. Calculated crystal fractionation paths for a FAMOUS basalt composition [Section 572-1-1, indicated by the star] from Bence et al. [1979] for $6 \%$ olivine fractionation followed by $24 \%$ [O] + Plag] fractionation in a 1:2 weight proportion are shown.

occur in many basalts recovered during Leg 64 . They consistently have more calcic cores $\left(\sim \mathrm{An}_{90}\right)$ than do coexisting phenocrysts and generally have slightly resorbed rims similar in composition to the phenocryst population ( $\sim \mathrm{An}_{80-64}$; Fig. 4, Table 3$)$. The central regions of the megacrysts are only slightly zoned, and the sodic rims are very narrow or absent. Comparison of the $\mathrm{Ca} / \mathrm{Ca}+\mathrm{Na}$ ratios of the megacryst cores with experimentally determined $\mathrm{Ca} / \mathrm{Ca}+\mathrm{Na}$ ratios in plagioclase crystallized from natural MORB (see Walker et al., 1979) indicates that the megacrysts are significantly more calcic than would be predicted if they had crystallized in equilibrium with their host magma. The rocks containing megacrysts should have plagioclase phenocrysts with compositions less than $\sim \mathrm{An}_{80}$, which, in fact, agrees with the observed phenocryst core compositions (Table 3).

Small amounts of $\mathrm{Fe}$ are present in all of the plagioclases analyzed. A positive correlation exists between sodium content and $\mathrm{Fe}$ abundance in plagioclase (Fig. 5). The interior portions of megacrysts (highest An) contain the least amount of $\mathrm{Fe}$, whereas their more sodic rims have $\mathrm{Fe}$ contents similar to those in phenocryst and groundmass plagioclase. Individual phenocrysts also show increasing $\mathrm{Fe}$ from calcic cores to sodic rims. This trend may be a consequence of increasing $\mathrm{Fe}+\mathrm{Na}$ content in residual liquids during crystallization of a magma. Mazzullo and Bence (1976) have noted a similar trend in basalts from the Nazca Plate and suggest that the Fe content may not continue to increase during the late stages of crystallization because of the onset of iron-titanium oxide crystallization.

It appears that the megacrysts could not have crystallized from their host basalts and therefore must be considered xenocrysts. The more sodic and slightly resorbed rims are further evidence that these xenocrysts tried to re-equilibrate with the magma. Their presence in many of the basalts suggests the possibility that magma mixing or plagioclase flotation may have occurred during evolution of these basalts.

\section{Pyroxene}

Pyroxenes in the basalts are predominantly calcic augites (Table 4), and variations in their major endmember components (Wo-En-Fs) are shown in the pyroxene quadrilateral (Fig. 6). Pyroxene crystallization trends involving depletions in $\mathrm{Ca}$ with decreasing $\mathrm{Mg}$ / $\mathrm{Mg}+\mathrm{Fe}$ are typical of tholeiitic magmas. Metastable 


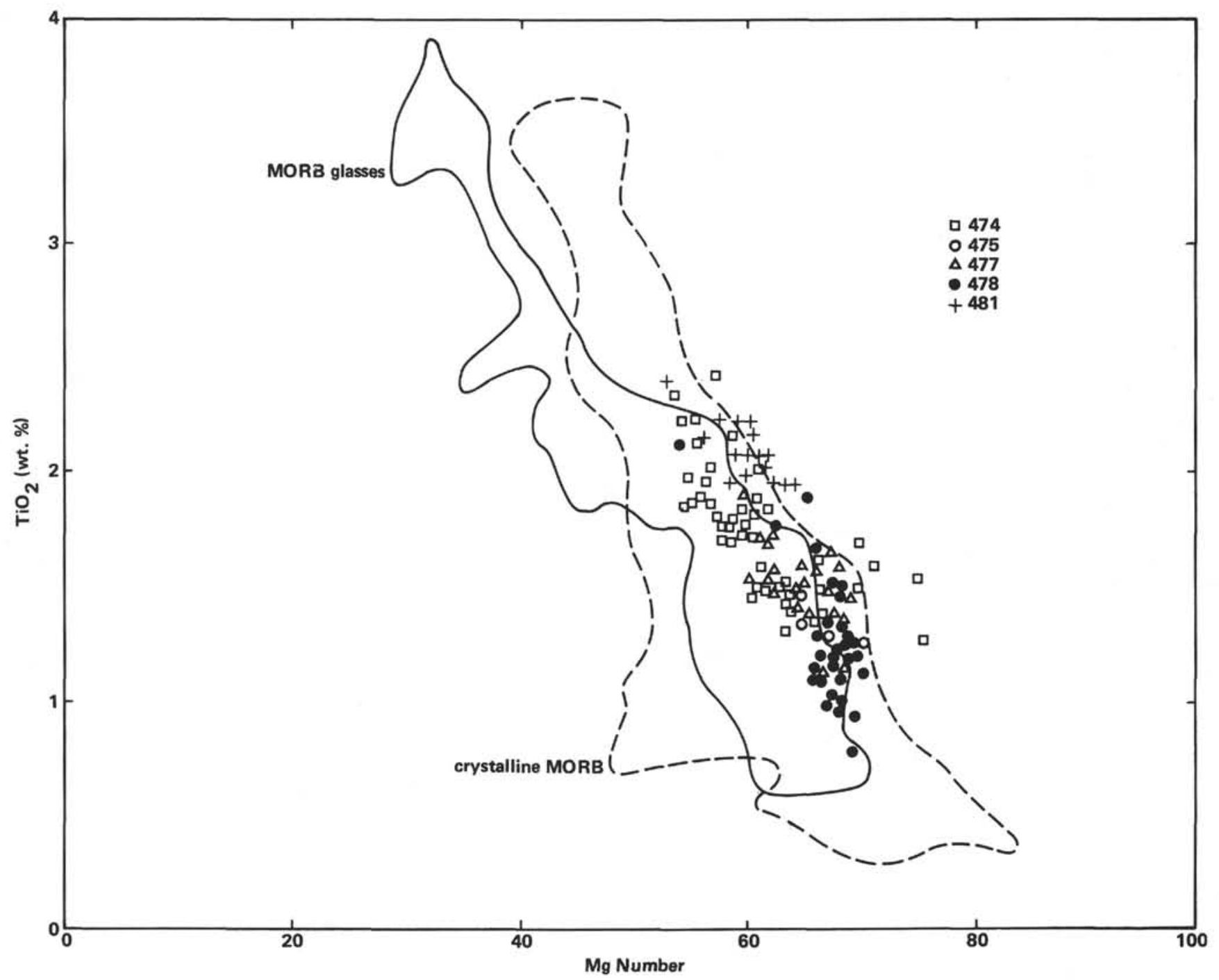

Figure 2. $\mathrm{TiO}_{2}$ versus $\mathrm{Mg}$ number $\left(\mathrm{Mg} / \mathrm{Mg}+\mathrm{Fe}^{2+} \times 100 ; \mathrm{Fe}\right.$ value used in $\mathrm{Mg}$ number calculation $\left.=0.9 \mathrm{FeO}\right)$ variation diagram, Leg 64 basalts. (Fields for MORB and MORB glasses are shown for comparison [see Fig. 1]. Note somewhat higher $\mathrm{TiO}_{2}$ contents at given $\mathrm{Mg}$ numbers in Leg 64 basalts.)

low-Ca clinopyroxenes, generally associated with rapid crystallization, do not occur in these basalts.

The percentages of nonquadrilateral components ("others" of Papike et al., 1974) are relatively low $(<14 \%)$ in all of the pyroxenes. Pyroxenes in basalts from Holes $474 \mathrm{~A}$ and 477 have greater proportions of "other" components than do pyroxenes from Hole 478 (Table 4). This is primarily a consequence of greater $\mathrm{Ti}$ and $\mathrm{Al}$ contents in the former. In the classification scheme of Papike et al. (1974) the best pyroxene endmember name for "others" would be CaMg-TAl for Holes 474A and 477; pyroxenes in basalts from Hole 478 would be classified as CaAl-CaTs (Fig. 7). There is a positive correlation between $\mathrm{Ti}$ and $\mathrm{Al}$ content in all of the pyroxenes at a fairly constant ratio of $1 \mathrm{Ti}$ to $4 \mathrm{Al}$ cations (Fig. 8). This is not a consequence of bulk rock composition, since rocks with the highest and lowest $\mathrm{TiO}_{2}$ or $\mathrm{Al}_{2} \mathrm{O}_{3}$ contents contain pyroxenes with similar $\mathrm{Ti}$ and $\mathrm{Al}$ abundances. Schweitzer et al. (1979) have shown that the $\mathrm{Ti}-\mathrm{Al}{ }^{\mathrm{iv}}$ substitution in crystals is one of the most important "others" pairs in pyroxenes of deep-sea basalts. For comparison with the data presented here, pyroxene data from Leg 34 on the Nazca Plate are plotted in Figure 8 and exhibit the same Ti-Al coupling. Shibata et al. (1979) also make mention of this feature in basalts from the North Atlantic.

Two complementary factors can cause the Ti- $\mathrm{Al}$ correlation. Since $\mathrm{Ti}$ and $\mathrm{Al}^{\mathrm{iv}}$ vary negatively with $\mathrm{Mg}$ (Fig. 9), a $\mathrm{Ti}-\mathrm{Al}$ buildup during fractionation is possible (Schweitzer et al., 1979). It has been shown, however, that the abundances of $\mathrm{Ti}$ and $\mathrm{Al}$ will increase with increased cooling rate during experimental pyroxene crystallization (Walker et al., 1976). Textural and mineralogical relations in the Leg 64 basalts suggest that latestage pyroxenes (i.e., groundmass and poikilitic) contain the greatest amounts of $\mathrm{Ti}$ and $\mathrm{Al}$, whereas subophitic-to-euhedral phenocrysts with higher $\mathrm{Mg} / \mathrm{Mg}+$ $\mathrm{Fe}^{2+}$ ratios contain less $\mathrm{Ti}$ and $\mathrm{Al}$. Coish and Taylor (1979) noted that some of the Ti-Al variation in Leg 34 pyroxenes result from rapid cooling of the margins of 


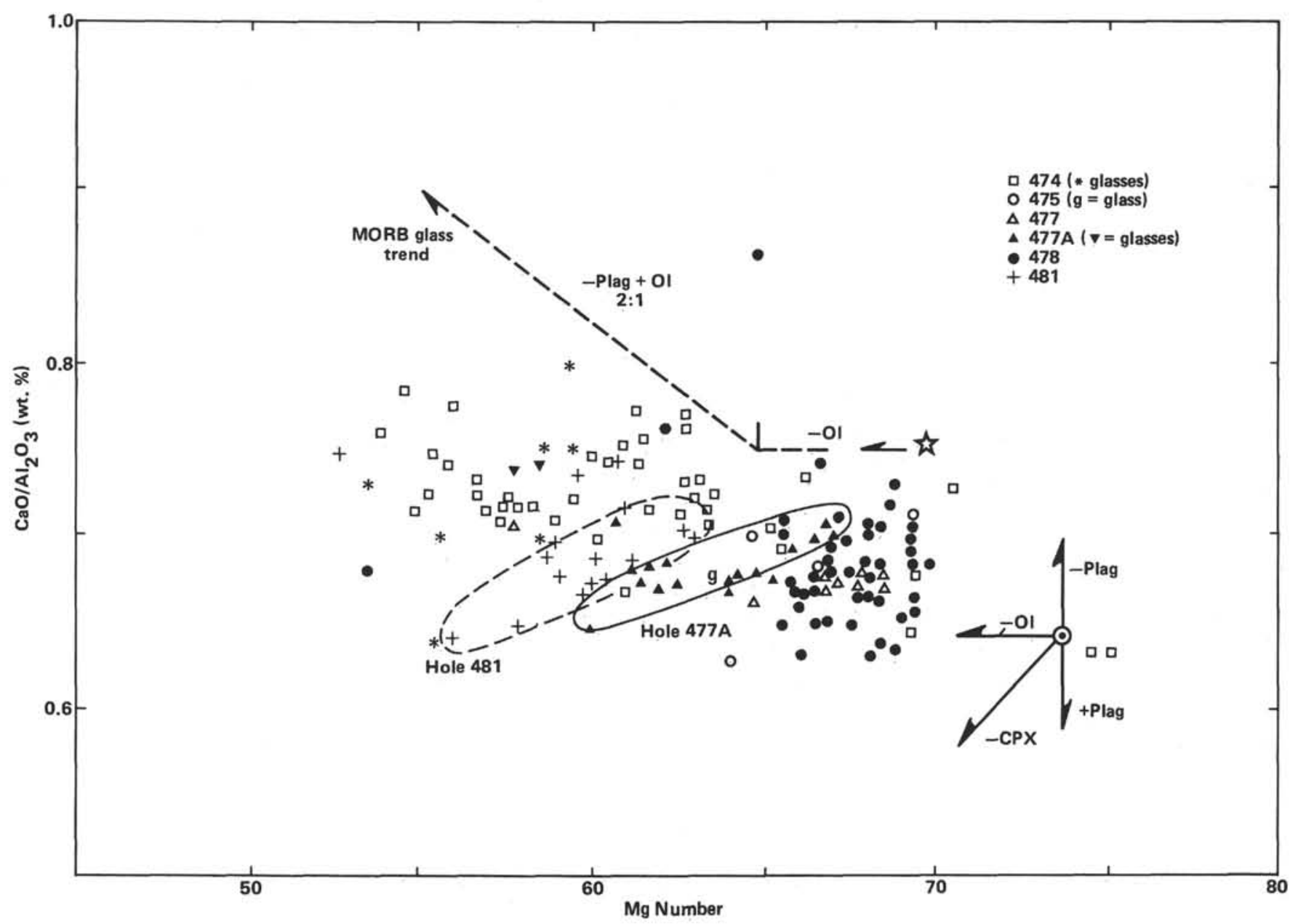

Figure 3. $\mathrm{CaO} / \mathrm{Al}_{2} \mathrm{O}_{3}$ versus $\mathrm{Mg}$-number variation diagram, Leg 64 basalts. (Fractionation trends calculated for FAMOUS basalt, Section 472-1-1, indicated by the star, are shown [Bence, et al., 1979; see Fig. 1]. Note that natural-glass analyses of Leg 64 basalts [Fornari et al., this volume] are indicated. Generalized fractionation/accumulation trends are presented for Ol, Plag, and Cpx.)

basalt units versus slow cooling in the interior portions. It appears that cooling rate plays a more important role than does the changing liquid composition in Leg 64 pyroxenes, since the late-stage crystallization of groundmass plagioclase and titanomagnetite (which would deplete the $\mathrm{Ti}$ and $\mathrm{Al}$ content in residual liquids) has little effect on the high $\mathrm{Ti}-\mathrm{Al}$ component in groundmass clinopyroxenes.

\section{Olivine}

Olivine phenocrysts and microphenocrysts have limited compositional ranges within the samples (Table 5, Fig. 6). With the exception of a microphenocryst in dolerite from Section 478-42-2, the entire compositional range is from $\mathrm{Fo}_{88.2}$ to $\mathrm{Fo}_{83.4}$ (Fig. 6). Similar ranges have been reported in phenocrysts from basalts drilled during Leg 34 (Mazzullo and Bence, 1976). Assuming that the distribution of $\mathrm{Fe}$ and $\mathrm{Mg}$ between olivine and liquid can vary between $\mathrm{Kd}=0.25$ and 0.35 , depending on the oxygen fugacity, temperature, and pressure during crystallization (see Walker et al., 1979; Bender et al., 1978), then it is likely that the olivines represent near-liquidus phases that crystallized in equilibrium with magmas having compositions not significantly different from their present host basalts (Mg numbers $\sim 60-65$ ). Rhodes et al. (1979), however, note that an addition (accumulation) of $5 \% \mathrm{Fo}_{90}$ to an evolved basalt with an $\mathrm{Mg}$ number of 56 will change it to a more primitive basalt $(\mathrm{Mg}$ number $=64)$ that only appears to be in equilibrium with the olivine.

\section{Opaque Minerals and Spinel}

Titanomagnetite is a ubiquitous groundmass phase in basalts; however, only a few were analyzed for this initial study (Table 6). The ulvospinel component varies from $\sim 75 \%$ in olivine-rich dolerite to $\sim 52 \%$ in a coarse-grained dolerite, where it coexists with ilmenite. Based on the Buddington and Lindsley (1964) geothermometer, equilibration of ilmenite and titanomagnetite occurred at approximately $1000^{\circ} \mathrm{C}$ and $\log f \mathrm{O}_{2}=-10.5$. Similar values were reported for coexisting oxides in Leg 34 basalts (Mazzullo and Bence, 1976).

Chromium-aluminum spinel occurs as inclusions in olivine and/or microphenocrysts in the more mafic ba- 
Table 3. Representative analyses of plagioclase, Holes $474 \mathrm{~A}, 477,478$.

\begin{tabular}{|c|c|c|c|c|c|c|c|c|c|c|c|c|c|c|c|c|c|c|}
\hline A & $\begin{array}{l}\text { alysis } \\
\text { mber }\end{array}$ & & Sample & $474 \mathrm{~A}-40-2$ & $38-40$ & & & Samp & $\begin{array}{l}474 \mathrm{~A}-42 \\
20-23\end{array}$ & & & & & Sam & le $474 \mathrm{~A}$ & $5-4,7-9$ & & \\
\hline Minera & 1 & 2 & 3 & 4 & 5 & 6 & 7 & 8 & 9 & 10 & $11 \mathrm{a}$ & $11 \mathrm{~b}$ & $11 \mathrm{c}$ & $11 \mathrm{e}$ & $11 \mathrm{f}$ & $11 \mathrm{~g}$ & $11 \mathrm{~h}$ & $11 \mathrm{i}$ \\
\hline $\mathrm{SiO}_{2}$ & 50.28 & 50.50 & 57.75 & 50.46 & 49.80 & 51.14 & 50.95 & 50.11 & 49.94 & 50.39 & 51.14 & 46.50 & 47.10 & 47.00 & 46.95 & 47.43 & 46.47 & 52.32 \\
\hline $\mathrm{Al}_{2} \mathrm{O}_{3}$ & 30.36 & 31.35 & 25.51 & 29.66 & 30.57 & 30.23 & 30.87 & 29.81 & 29.45 & 29.84 & 29.63 & 33.83 & 33.28 & 33.09 & 33.65 & 33.76 & 33.61 & 29.75 \\
\hline $\mathrm{FeO}^{+}$ & 0.49 & 0.40 & 0.45 & 0.73 & 0.41 & 0.36 & 0.52 & 0.54 & 0.41 & 0.33 & 1.10 & 0.31 & 0.30 & 0.26 & 0.29 & 0.33 & 0.32 & 0.53 \\
\hline $\mathrm{MgO}$ & & & & 0.27 & & & & & 0.21 & & 0.55 & & & & & 0.23 & & \\
\hline $\mathrm{CaO}$ & 14.59 & 15.04 & 8.27 & 14.11 & 14.33 & 14.51 & 14.65 & 14.03 & 13.74 & 13.81 & 14.01 & 18.22 & 17.78 & 17.62 & 17.81 & 17.95 & 18.32 & 13.93 \\
\hline $\begin{array}{l}\mathrm{Na}_{2} \mathrm{O} \\
\mathrm{K}_{2} \mathrm{O}\end{array}$ & 3.56 & 3.29 & 6.96 & 3.41 & 3.56 & 3.27 & 3.22 & 3.17 & 3.32 & 3.61 & $\begin{array}{l}3.3 \\
0.08\end{array}$ & 1.03 & 1.24 & 1.23 & 1.05 & 1.42 & 1.10 & 3.84 \\
\hline Total & 99.27 & 100.57 & 98.95 & 98.63 & 98.66 & 98.51 & 100.21 & 97.66 & 97.07 & 97.99 & 99.81 & 99.98 & 99.70 & 99.20 & 99.75 & 101.01 & 99.82 & 100.36 \\
\hline & & & & & & & & Cation & based on & 32 oxyge & & & & & & & & \\
\hline $\mathrm{Sl}$ & 9.262 & 9.178 & 10.454 & 9.345 & 9.222 & 9.364 & 9.277 & 9.351 & 9.370 & 9.367 & 9.363 & 8.570 & 8.685 & 8.704 & 8.647 & 8.625 & 9.579 & 9.494 \\
\hline Al & 6.592 & 6.717 & 5.445 & 6.476 & 6.674 & 6.526 & 6.627 & 6.557 & 6.514 & 6.540 & 6.399 & 7.350 & 7.224 & 7.224 & 7.307 & 7.254 & 7.315 & 6.365 \\
\hline $\mathrm{Fe}$ & 0.076 & 0.061 & 0.068 & 0.113 & 0.063 & 0.055 & 0.080 & 0.084 & 0.064 & 0.052 & 0.169 & 0.048 & 0.046 & 0.039 & 0.045 & 0.051 & 0.049 & 0.080 \\
\hline $\mathrm{Mg}$ & & & & 0.073 & & & & & 0.059 & & 0.151 & & & & & 0.063 & & \\
\hline $\mathrm{Ca}$ & 2.879 & 2.928 & 1.605 & 2.799 & 2.843 & 2.846 & 2.858 & 2.805 & 2.762 & 2.752 & 2.751 & 3.600 & 3.512 & 3.496 & 3.515 & 3.505 & 3.623 & 2.709 \\
\hline $\mathrm{Na}$ & 1.269 & 1.158 & 2.442 & 1.222 & 1.277 & 1.161 & 1.136 & 1.147 & 1.207 & 1.302 & 1.172 & 0.370 & 0.443 & 0.442 & 0.373 & 0.500 & 0.394 & 1.349 \\
\hline K & & & & & & & & & & & 0.019 & & & & & & & \\
\hline Total & 20.007 & 20.042 & 20.013 & 20.028 & 20.079 & 19.953 & 19.977 & 19.944 & 19.976 & 20.013 & 20.028 & 19.937 & 19.919 & 19.905 & 19.886 & 19.998 & 19.960 & 19.997 \\
\hline An & 69.4 & 71.7 & 39.7 & 69.6 & 71.0 & 71.0 & 71.6 & 71.0 & 69.6 & 67.9 & 69.8 & 90.7 & 88.8 & 88.8 & 90.4 & 87.5 & 90.2 & 66.8 \\
\hline
\end{tabular}

Note: Total Fe as FeO; blank means not detected. Analysis numbers: 1-7, intermediate to central points in groundmass microphenocrysts; 8-10, groundmass microphenocrysts; 11a-11e, rim to core of large megacryst; 11f-11i, core to rim of same megacryst; 12, groundmass microphenocryst. 13a-13f, rim to core of megacryst; 14-16, groundmass microlites; 23a-23d, rim to core of megacryst; $24-25$, groundmass phenocrysts; 26 , microphenocryst. 17, phenocryst; $18 \mathrm{a}-18 \mathrm{~d}$ rim to core of megacryst; 19-20, 22, phenocrysts; 21, groundmass; $29 \mathrm{a}-29 \mathrm{~b}$, core and rim of phenocryst enclosed in clinopyroxene; 30 , core phenocryst; $31-34$, cores of phenocrysts.

Table 3. (Continued).

\begin{tabular}{|c|c|c|c|c|c|c|c|c|c|c|c|c|c|c|c|c|c|c|}
\hline \multirow[b]{2}{*}{12} & \multicolumn{9}{|c|}{ Sample $474 A-46-3,80-82$} & \multicolumn{7}{|c|}{ Sample 474A-49-3, 146-149 } & \multirow[b]{2}{*}{17} & \multirow[b]{2}{*}{$18 \mathrm{a}$} \\
\hline & 13a & $13 \mathrm{~b}$ & $13 \mathrm{c}$ & $13 \mathrm{~d}$ & $13 e$ & $13 \mathrm{f}$ & 14 & 15 & 16 & $23 a$ & $23 \mathrm{~b}$ & $23 \mathrm{c}$ & $23 \mathrm{~d}$ & 24 & 25 & 26 & & \\
\hline 50.79 & 48.68 & 45.24 & 46.13 & 45.61 & 45.57 & 47.58 & 47.88 & 50.82 & 50.43 & 50.99 & 46.35 & 46.37 & 46.30 & 52.31 & 52.31 & 52.79 & 49.18 & 52.03 \\
\hline 30.83 & 31.12 & 33.83 & 33.31 & 33.72 & 33.79 & 33.46 & 31.95 & 30.17 & 30.96 & 30.50 & 44.03 & 34.49 & 33.87 & 30.19 & 29.60 & 28.61 & 30.95 & 29.15 \\
\hline 0.51 & 0.38 & 0.35 & 0.34 & 0.27 & 0.34 & 0.29 & 0.46 & $\begin{array}{l}0.48 \\
0.25\end{array}$ & $\begin{array}{l}0.68 \\
0.24\end{array}$ & 0.49 & 0.35 & 0.37 & 0.37 & 0.71 & $\begin{array}{l}0.87 \\
0.33\end{array}$ & 0.83 & 0.40 & 0.69 \\
\hline 14.97 & 15.73 & 18.20 & 17.94 & 18.13 & 18.39 & 18.29 & 16.46 & 14.78 & 15.31 & 14.80 & 18.39 & 18.17 & 18.10 & 14.00 & 13.71 & 13.13 & 15.08 & 13.29 \\
\hline 3.10 & 2.18 & 0.91 & 1.14 & 0.93 & 0.92 & 1.03 & 1.87 & 3.00 & 2.86 & 3.12 & 0.99 & 0.91 & 1.10 & 3.65 & $\begin{array}{l}3.42 \\
0.13\end{array}$ & 4.08 & 2.63 & 4.15 \\
\hline 100.20 & 98.09 & 98.55 & 98.86 & 98.65 & 99.01 & 98.65 & 98.62 & 99.51 & 100.48 & 99.89 & 100.11 & 100.25 & 99.73 & 100.85 & 100.36 & 99.44 & 98.22 & 99.31 \\
\hline \multicolumn{19}{|c|}{ Cations based on 32 oxygens } \\
\hline 9.246 & 9.074 & 8.460 & 8.593 & 8,516 & 8.489 & 8.521 & 8.903 & 9.318 & 9.185 & 9.313 & 8.532 & 8.511 & 8.511 & 9.450 & 9.494 & 9.659 & 9.144 & 9.544 \\
\hline 6.617 & 6.837 & 7.458 & 7.316 & 7.421 & 7.420 & 7.375 & 7.004 & 6.522 & 6.646 & 6.568 & 7.384 & 7.463 & 7.375 & 6.430 & 6.335 & 6.172 & 6.783 & 6.304 \\
\hline 0.077 & 0.059 & 0.005 & 0.053 & 0.042 & 0.054 & 0.045 & 0.071 & $\begin{array}{l}0.074 \\
0.068\end{array}$ & $\begin{array}{l}0.103 \\
0.064\end{array}$ & 0.075 & 0.054 & 0.048 & 0.057 & 0.107 & $\begin{array}{l}0.132 \\
0.090\end{array}$ & 0.127 & 0.061 & 0.106 \\
\hline 2.921 & 3.142 & 3.647 & 3.580 & 3.627 & 3.671 & 3.663 & 3.280 & 2.904 & 2.988 & 2.896 & 3.628 & 3.573 & 3.582 & 2.709 & 2.666 & 2.574 & 3.003 & 2.613 \\
\hline 1.092 & 0.788 & 0.331 & 0.411 & 0.335 & 0.333 & 0.374 & 0.675 & 1.067 & 1.011 & 1.103 & 0.354 & 0.325 & 0.393 & 1.278 & $\begin{array}{l}1.205 \\
0.030\end{array}$ & 1.448 & 0.946 & 1.476 \\
\hline 19.972 & 19.901 & 19.968 & 19.954 & 19.941 & 19.967 & 19.978 & 19.932 & 19.954 & 19.997 & 19.954 & 19.952 & 19.920 & 19.958 & 19.974 & 19.953 & 19.979 & 19.937 & 20.042 \\
\hline 72.8 & 79.9 & 91.7 & 89.7 & 91.5 & 91.7 & 90.7 & 82.9 & 73.1 & 74.7 & 72.4 & 91.1 & 91.7 & 90.1 & 67.9 & 68.4 & 64.0 & 76.1 & 63.9 \\
\hline
\end{tabular}

Table 3. (Continued).

\begin{tabular}{|c|c|c|c|c|c|c|c|c|c|c|c|c|c|c|c|c|}
\hline \multicolumn{7}{|c|}{ Sample $477-13-2,145-146$} & \multicolumn{6}{|c|}{ Sample $478-42-2,82-83$} & \multicolumn{4}{|c|}{ Sample $478-51-3,52-53$} \\
\hline $18 \mathrm{~b}$ & $18 \mathrm{c}$ & $18 \mathrm{~d}$ & 19 & 20 & 21 & 22 & $27 \mathrm{a}$ & $27 \mathrm{~b}$ & 28 & $29 a$ & $29 \mathrm{~b}$ & $30^{\circ}$ & 31 & 32 & 33 & 34 \\
\hline 46.44 & 45.87 & 46.25 & 50.47 & 50.10 & 51.21 & 46.80 & 52.45 & 60.43 & 49.94 & 53.85 & 53.77 & 53.13 & 55.14 & 57.31 & 54.59 & 56.02 \\
\hline 33.63 & 33.71 & 33.77 & 30.57 & 30.81 & 30.22 & 33.99 & 29.53 & 24.57 & 30.99 & 28.61 & 28.80 & 29.17 & 27.92 & 26.82 & 28.48 & 26.92 \\
\hline 0.18 & 0.27 & 0.31 & 0.40 & 0.46 & 0.70 & 0.31 & 0.51 & 0.66 & 0.35 & 0.47 & 0.52 & $\begin{array}{l}0.47 \\
0.23\end{array}$ & 0.51 & 0.48 & 0.50 & 0.49 \\
\hline $\begin{array}{r}18.08 \\
1.12\end{array}$ & $\begin{array}{r}18.08 \\
1.14\end{array}$ & $\begin{array}{r}17.97 \\
1.22\end{array}$ & $\begin{array}{r}14.56 \\
3.41\end{array}$ & $\begin{array}{r}15.05 \\
3.09\end{array}$ & $\begin{array}{r}14.04 \\
3.60\end{array}$ & $\begin{array}{r}17.94 \\
1.00\end{array}$ & $\begin{array}{r}13.07 \\
4.09\end{array}$ & $\begin{array}{l}6.96 \\
6.86 \\
0.16\end{array}$ & $\begin{array}{r}15.22 \\
2.43\end{array}$ & $\begin{array}{r}12.24 \\
4.73\end{array}$ & $\begin{array}{r}12.43 \\
4.73\end{array}$ & $\begin{array}{r}12.74 \\
4.37\end{array}$ & $\begin{array}{r}11.66 \\
5.01\end{array}$ & $\begin{array}{l}9.82 \\
5.82\end{array}$ & $\begin{array}{r}12.17 \\
4.74\end{array}$ & $\begin{array}{r}10.28 \\
5.52 \\
0.08\end{array}$ \\
\hline 99.45 & 99.07 & 99.52 & 99.41 & 99.59 & 99.76 & 99.05 & 99.65 & 99.64 & 98.93 & 99.90 & 100.25 & 100.11 & 100.24 & 100.24 & 100.47 & 99.31 \\
\hline \multicolumn{17}{|c|}{ Cations based on 32 oxygens } \\
\hline $\begin{array}{l}8.592 \\
7.335\end{array}$ & $\begin{array}{l}8.530 \\
7.392\end{array}$ & $\begin{array}{l}8.559 \\
7.369\end{array}$ & $\begin{array}{l}9.269 \\
6.619\end{array}$ & $\begin{array}{l}9.201 \\
6.671\end{array}$ & $\begin{array}{l}9.357 \\
6.508\end{array}$ & $\begin{array}{l}8.599 \\
7.364\end{array}$ & $\begin{array}{l}9.554 \\
6.343\end{array}$ & $\begin{array}{r}10.782 \\
5.168\end{array}$ & 9.204 & 9.170 & 9.718 & 9.634 & 9.945 & 10.268 & 9.836 & $\begin{array}{r}10.147 \\
5.749\end{array}$ \\
\hline $\begin{array}{l}7.335 \\
0.028\end{array}$ & $\begin{array}{l}7.392 \\
0.042\end{array}$ & $\begin{array}{l}7.369 \\
0.048\end{array}$ & $\begin{array}{l}6.619 \\
0.062\end{array}$ & $\begin{array}{l}6.671 \\
0.070\end{array}$ & $\begin{array}{l}6.508 \\
0.107\end{array}$ & $\begin{array}{l}7.364 \\
0.040\end{array}$ & $\begin{array}{l}6.343 \\
0.077\end{array}$ & $\begin{array}{l}5.168 \\
0.099\end{array}$ & $\begin{array}{l}6.733 \\
0.054\end{array}$ & $\begin{array}{l}6.120 \\
0.071\end{array}$ & $\begin{array}{l}6.127 \\
0.078\end{array}$ & $\begin{array}{l}6.238 \\
0.071 \\
0.062\end{array}$ & $\begin{array}{l}5.936 \\
0.077\end{array}$ & $\begin{array}{l}5.664 \\
0.072\end{array}$ & $\begin{array}{l}6.051 \\
0.075\end{array}$ & $\begin{array}{l}5.749 \\
0.074\end{array}$ \\
\hline $\begin{array}{l}3.585 \\
0.400\end{array}$ & $\begin{array}{l}3.604 \\
0.410\end{array}$ & $\begin{array}{l}3.563 \\
0.437\end{array}$ & $\begin{array}{l}2.865 \\
1.214\end{array}$ & $\begin{array}{l}2.962 \\
1.099\end{array}$ & $\begin{array}{l}2.748 \\
1.274\end{array}$ & $\begin{array}{l}3.531 \\
0.357\end{array}$ & $\begin{array}{l}2.552 \\
1.446\end{array}$ & $\begin{array}{l}1.331 \\
2.372 \\
0.036\end{array}$ & $\begin{array}{l}3.005 \\
0.867\end{array}$ & $\begin{array}{l}2.379 \\
1.663\end{array}$ & $\begin{array}{l}2.406 \\
1.656\end{array}$ & $\begin{array}{l}2.475 \\
1.537\end{array}$ & $\begin{array}{l}2.252 \\
1.751\end{array}$ & $\begin{array}{l}1.886 \\
2.020\end{array}$ & $\begin{array}{l}2.349 \\
1.656\end{array}$ & $\begin{array}{l}1.996 \\
1.939 \\
0.018\end{array}$ \\
\hline 19.94 & 19.978 & 19.975 & 20.029 & 20.022 & 19.994 & 19.897 & 19.972 & 19.813 & 19.863 & 20.002 & 19.995 & 20.016 & 19.962 & 19.910 & 19.966 & 19.924 \\
\hline 90.0 & 89.8 & 89.1 & 70.2 & 72.6 & 68.3 & 90.8 & 63.8 & 35.6 & 77.6 & 58.9 & 59.2 & 61.7 & 56.3 & 48.3 & 58.7 & 50.5 \\
\hline
\end{tabular}


salts recovered during Leg 64 . Three representative analyses are presented in Table 7. They are characterized by relatively low $\mathrm{Cr} / \mathrm{Cr}+\mathrm{Al}$ ratios and high $\mathrm{Mg}$ / $\mathrm{Mg}+\mathrm{Fe}^{2+}$ ratios. They are compositionally most similar to the Al-rich spinels observed in some FAMOUS basalts (Fisk and Bence, 1980) and picrites from the MidAtlantic Ridge (Sigurdsson and Schilling, 1976). The experimental results of Fisk and Bence (1980) indicate that these Al-rich spinels may have crystallized from a $\mathrm{Mg}$ rich liquid (similar to Sample 474A-42-1, $6 \mathrm{~cm}$ ) at low pressure (1 atm.) or, alternatively, at higher pressures and temperatures $>1250^{\circ} \mathrm{C}$.

\section{FRACTIONAL CRYSTALLIZATION MODELS}

To test the hypothesis that some of the major- and trace-element variations in the basalts drilled during Leg 64 result from fractional crystallization and to determine quantitatively the proportions of the phases that could have been removed, a large number of fractional crystallization calculations were performed using a leastsquares mixing program adapted from Wright and Doherty $(1970)$ (Tables 8, 9). Whole-rock data were used as parental and derivative liquid compositions (Table 1); consequently, possible inaccuracies may be attributed to the high phenocryst contents of some samples. The compositions of fractionated phases were taken from probe analyses of minerals in the least-fractionated samples from each hole. The program has the option of determining the best end-member composition for plagioclase and olivine. Thus, the computed An and Fo contents are given in Tables 8 and 9. The program can also determine whether a better fit is achieved by addition or by removal of a phase. In the few models where a negative sign appears in front of the mineral percentage, it means that the phase is in excess in the derivative liquid (i.e., crystal accumulation). With the exception of Models 1 and 14 (Table 8), the spinel composition used in the calculations was titanomagnetite rather than $\mathrm{Cr}-\mathrm{Al}$ spinel. The "comments" column lists the oxides with the poorest computed "fit"' (i.e., the largest percent difference between computed-parent and observed-parent composition), thus contributing substantially to the sum of the squares of residuals $\left(\Sigma r^{2}\right)$. A positive sign signifies that the oxide was calculated in excess in the parental liquid. The fact that $\mathrm{K}_{2} \mathrm{O}$ often results in a poor fit is not considered a serious problem, because it is so susceptible to secondary alteration.

Table 4. Representative clinopyroxene analyses, Holes 474A, 477, and 478.

\begin{tabular}{|c|c|c|c|c|c|c|c|c|c|c|c|c|}
\hline \multirow{2}{*}{$\begin{array}{l}\text { Analysis } \\
\text { Number }\end{array}$} & \multicolumn{7}{|c|}{ Sample $474 A-40-2,38-40$} & \multicolumn{5}{|c|}{$474 \mathrm{~A}-45-4,7-9$} \\
\hline & 1 & $2 b$ & 3 & 4 & 5 & 6 & 7 & 8 & 9 & 11 & 12 & 13 \\
\hline $\mathrm{SiO}_{2}$ & 48.76 & 48.59 & 47.80 & 46.47 & 47.33 & 47.63 & 47.99 & 49.32 & 48.02 & 49.35 & 49.72 & 49.45 \\
\hline $\mathrm{Al}_{2} \mathrm{O}_{3}$ & 3.55 & 4.41 & 5.07 & 5.52 & 5.80 & 5.95 & 5.68 & 3.08 & 4.85 & 3.49 & 4.56 & 4.67 \\
\hline $\mathrm{TiO}_{2}$ & 1.96 & 2.28 & 2.54 & 4.02 & 2.88 & 2.92 & 2.62 & 1.41 & 1.93 & 1.45 & 1.44 & 1.66 \\
\hline $\mathrm{MgO}$ & 13.11 & 12.85 & 12.82 & 10.86 & 12.18 & 12.81 & 12.68 & 13.46 & 13.58 & 14.15 & 13.98 & 13.50 \\
\hline $\mathrm{FeO}$ & 8.96 & 9.19 & 8.07 & 10.64 & 8.88 & 8.29 & 8.57 & 12.11 & 8.39 & 8.64 & 8.05 & 8.66 \\
\hline $\mathrm{MnO}$ & 0.15 & 0.20 & 0.14 & 0.26 & 0.12 & 0.12 & 0.12 & 0.22 & 0.12 & 0.15 & 0.34 & 0.02 \\
\hline $\mathrm{CaO}$ & 21.39 & 21.62 & 21.94 & 21.17 & 22.88 & 21.72 & 21.73 & 18.51 & 20.20 & 20.03 & 21.51 & 21.15 \\
\hline $\mathrm{Na}_{2} \mathrm{O}$ & 0.52 & 0.63 & 0.43 & 0.55 & 0.41 & 0.64 & 0.63 & 0.40 & 0.00 & 0.00 & 0.40 & 0.00 \\
\hline $\mathrm{Cr}_{2} \mathrm{O}_{3}$ & 0.21 & 0.13 & 0.13 & 0.00 & 0.23 & 0.50 & 0.13 & 0.00 & 0.33 & 0.18 & 0.34 & 0.32 \\
\hline \multirow[t]{2}{*}{ Total } & 98.61 & 99.90 & 98.94 & 99.49 & 100.71 & 100.58 & 100.15 & 98.51 & 97.42 & 97.44 & 100.34 & 99.62 \\
\hline & \multicolumn{12}{|c|}{ Cations Based on 6.0 Oxygens } \\
\hline $\mathrm{Si}$ & 1.857 & 1.830 & 1.810 & 1.773 & 1.774 & 1.777 & 1.798 & 1.887 & 1.836 & 1.884 & 1.849 & 1.850 \\
\hline $\mathrm{Al}$ & 0.143 & 0.170 & 0.190 & 0.227 & 0.226 & 0.223 & 0.202 & 0.113 & 0.164 & 0.116 & 0.151 & 0.150 \\
\hline 乏TET & 2.000 & 2.000 & 2.000 & 2.000 & 2.000 & 2.000 & 2.000 & 2.000 & 2.000 & 2.000 & 2.000 & 2.000 \\
\hline $\mathrm{Al}^{\mathrm{vi}}$ & 0.016 & 0.025 & 0.036 & 0.021 & 0.030 & 0.039 & 0.048 & 0.026 & 0.055 & 0.041 & 0.049 & 0.056 \\
\hline $\mathrm{Ti}$ & 0.056 & 0.065 & 0.072 & 0.115 & 0.081 & 0.082 & 0.074 & 0.041 & 0.055 & 0.042 & 0.040 & 0.047 \\
\hline $\mathrm{Mg}$ & 0.744 & 0.721 & 0.724 & 0.618 & 0.680 & 0.713 & 0.708 & 0.768 & 0.774 & 0.805 & 0.775 & 0.752 \\
\hline $\mathrm{Fe}$ & 0.285 & 0.289 & 0.256 & 0.339 & 0.278 & 0.259 & 0.268 & 0.388 & 0.268 & 0.276 & 0.250 & 0.271 \\
\hline Mn & 0.005 & 0.006 & 0.004 & 0.008 & 0.004 & 0.004 & 0.004 & 0.007 & 0.004 & 0.005 & 0.011 & 0.006 \\
\hline $\mathrm{Ca}$ & 0.873 & 0.872 & 0.890 & 0.865 & 0.919 & 0.868 & 0.872 & 0.759 & 0.828 & 0.819 & 0.857 & 0.848 \\
\hline $\mathrm{Na}$ & 0.038 & 0.046 & 0.032 & 0.041 & 0.030 & 0.046 & 0.046 & 0.030 & 0.000 & 0.000 & 0.029 & 0.000 \\
\hline $\mathrm{Cr}$ & 0.006 & 0.004 & 0.004 & 0.000 & 0.007 & 0.015 & 0.004 & 0.000 & 0.010 & 0.005 & 0.010 & 0.010 \\
\hline ¿Cations & 4.024 & 4.029 & 4.018 & 4.008 & 4.029 & 4.026 & 4.024 & 4.018 & 3.994 & 3.993 & 4.020 & 3.989 \\
\hline En & 39.0 & 38.2 & 38.6 & 33.7 & 36.2 & 38.7 & 38.2 & 40.0 & 41.3 & 42.3 & 40.9 & 40.2 \\
\hline Fs & 15.2 & 15.6 & 13.9 & 19.0 & 15.0 & 14.2 & 14.7 & 20.5 & 14.5 & 14.7 & 13.8 & 14.5 \\
\hline Wo & 45.8 & 46.2 & 47.5 & 47.3 & 48.8 & 47.1 & 47.1 & 39.5 & 44.2 & 43.0 & 45.3 & 45.3 \\
\hline Quad & 92.3 & 90.8 & 88.8 & 86.4 & 88.4 & 86.6 & 87.5 & 93.4 & 89.1 & 92.5 & 90.2 & 90.1 \\
\hline Others & 7.7 & 9.2 & 11.2 & 13.6 & 11.6 & 13.4 & 12.5 & 6.6 & 10.9 & 7.5 & 9.8 & 9.9 \\
\hline $\mathrm{Mg} / \mathrm{Mg}+\mathrm{Fe}$ & 0.723 & 0.714 & 0.739 & 0.645 & 0.710 & 0.734 & 0.725 & 0.665 & 0.743 & 0.745 & 0.756 & 0.735 \\
\hline
\end{tabular}

Note: All Fe as $\mathrm{FeO} ; 1-7$, clinopyroxenes in groundmass, interstitial grains; 8-11, groundmass clinopyroxene; 12-13, subophitic; 14-15, clinopyroxene crystals; 19-25, subhedral subophitic grains; 27 , larger phenocryst partially enclosing 26; 28-29, ophitic phenocrysts; Rim (30A) and core (30B) of single grain. 


\section{Hole 474A}

The suite of Hole 474A basalts exhibits a wide range of chemical compositions and a significant degree of differentiation. Variations in $\mathrm{CaO} / \mathrm{Al}_{2} \mathrm{O}_{3}$ with $\mathrm{Mg}$ number (Fig. 3) suggest strong $\mathrm{Ol}+\mathrm{Plag}$ control of fractionation. Saunders et al. (this volume) suggest that olivine and spinel accumulation may account for the high $\mathrm{MgO}, \mathrm{Cr}$, and $\mathrm{Ni}$ in picritic basalts such as those from Samples 474A-42-1, $6 \mathrm{~cm}$ and 474A-40-1, $19 \mathrm{~cm}$. Model 1 suggests that an olivine-rich dolerite (Sample $474 \mathrm{~A}-40-2,40 \mathrm{~cm}$ ) could be derived from picrite by $\mathrm{Ol}+\mathrm{Spnl}$ fractionation or, alternatively, that the picrite contains about $15 \%$ cumulate olivine + spinel. Similarly, the derivation of a more typical basalt (Sample $474 \mathrm{~A}-39-3,148 \mathrm{~cm}$ ) from picrite or olivine-rich dolerite (Models 2, 15, 16) requires the removal of large percentages of olivine $\left(\mathrm{FO}_{90}\right)$. Considering the heterogeneous distribution of olivine phenocrysts in Units 1 and 2, it is likely that the picritic lavas are, in part, cumulate. Smaller percentages of plagioclase \pm clinopyroxene \pm spinel must also be removed, however, to generate more fractionated basalts, suggesting that olivine subtraction or accumulation alone cannot explain the major-element trends.
Petrographic evidence indicates that $\mathrm{Plag}+\mathrm{Ol} \pm \mathrm{Cr}-$ spinel are near-liquidus phases in the more mafic basalts and should control the early liquid line of descent. Models 4 and 12 indicate that this scheme, with approximately 2 parts Plag to 1 part $\mathrm{Ol}$, is fairly successful. In comparison to Model 4, however, Model 5 results in a better fit (lower $\Sigma r^{2}$ ) when Cpx is included as a fractionating phase. In fact, in deriving the more evolved rocks (Samples 474A-50-3, $91 \mathrm{~cm}, 474 \mathrm{~A}-50-4,1 \mathrm{~cm}, 474 \mathrm{~A}-49-$ $2,31 \mathrm{~cm}$ ), Cpx fractionation is essential (see Models 5$11,17)$. Clinopyroxene fractionation must have occurred at higher pressures (deeper depths), according to the experimental work of Bender et al. (1978), and there is little petrographic evidence for this occurrence, because no Cpx phenocrysts occur in the Hole 474 rocks. Plagioclase continues to dominate the fractionating assemblage, which explains the rapid decrease in $\mathrm{Al}_{2} \mathrm{O}_{3}$ with $\mathrm{MgO}$ in Figure 1.

The calculations support the proposals of Saunders et al. (this volume) that basalts from Units 6,7 , and 8 can be related by fractional crystallization of Plag + $\mathrm{Ol}+\mathrm{Cpx}$ from the same or a similar parental magma. Since the proportions of fractionating minerals are so variable, however, the calculations suggest that the basalts are not all related by the same liquid line of de-

Table 4. (Continued).

\begin{tabular}{|c|c|c|c|c|c|c|c|c|c|c|c|c|c|c|}
\hline \multicolumn{2}{|c|}{$\begin{array}{c}\text { Sample 477-13-2, } \\
145-146\end{array}$} & \multicolumn{9}{|c|}{ Sample $478-42-2,82-83$} & \multicolumn{4}{|c|}{ Sample $478-51-3,52-53$} \\
\hline 14 & 15 & 19 & 20 & 21 & 22 & 23 & 24 & 25 & 26 & 27 & 28 & 29 & $30 \mathrm{~A}$ & 30B \\
\hline 48.95 & 49.96 & 51.71 & 51.78 & 51.07 & 51.37 & 52.94 & 51.21 & 52.55 & 51.85 & 52.02 & 51.41 & 51.75 & 51.29 & 51.96 \\
\hline 5.06 & 5.02 & 2.86 & 2.69 & 3.49 & 3.30 & 2.17 & 3.72 & 1.89 & 2.28 & 2.39 & 2.40 & 1.99 & 2.70 & 2.62 \\
\hline 2.25 & 2.13 & 0.92 & 0.88 & 0.87 & 0.80 & 0.53 & 0.81 & 0.58 & 1.34 & 1.29 & 1.39 & 0.98 & 1.24 & 0.97 \\
\hline 13.06 & 13.50 & 15.59 & 15.90 & 15.81 & 15.72 & 17.14 & 16.10 & 16.37 & 14.29 & 14.92 & 14.66 & 15.61 & 15.42 & 15.65 \\
\hline 8.74 & 8.47 & 7.00 & 6.91 & 6.78 & 5.64 & 5.00 & 5.00 & 6.48 & 9.06 & 8.46 & 9.00 & 8.42 & 7.49 & 7.26 \\
\hline 0.14 & 0.14 & 0.18 & 0.12 & 0.16 & 0.14 & 0.19 & 0.00 & 0.00 & 0.19 & 0.12 & 0.19 & 0.22 & 0.18 & 0.23 \\
\hline 21.02 & 21.60 & 21.23 & 21.05 & 20.78 & 21.45 & 20.93 & 21.87 & 21.32 & 20.90 & 20.66 & 20.82 & 19.75 & 20.98 & 21.35 \\
\hline 0.40 & 0.00 & 0.51 & 0.50 & 0.54 & 0.41 & 0.45 & 0.55 & 0.00 & 0.00 & 0.00 & 0.41 & 0.64 & 0.00 & 0.00 \\
\hline 0.27 & 0.33 & 0.23 & 0.14 & 0.50 & 0.42 & 0.34 & 0.51 & 0.14 & 0.00 & 0.17 & 0.00 & 0.13 & 0.13 & 0.00 \\
\hline 99.89 & 100.15 & 100.23 & 99.97 & 100.00 & 99.25 & 99.69 & 99.77 & 99.33 & 99.91 & 100.03 & 100.28 & 99.49 & 99.43 & 100.04 \\
\hline \multicolumn{15}{|c|}{ Cations Based on 6.0 Oxygens } \\
\hline 1.832 & 1.826 & 1.908 & 1.913 & 1.887 & 1.904 & 1.941 & 1.885 & 1.945 & 1.930 & 1.927 & 1.911 & 1.930 & 1.908 & 1.919 \\
\hline 0.168 & 0.174 & 0.092 & 0.087 & 0.113 & 0.096 & 0.059 & 0.115 & 0.055 & 0.070 & 0.073 & 0.089 & 0.070 & 0.092 & 0.091 \\
\hline 2.000 & 2.000 & 2.000 & 2.000 & 2.000 & 2.000 & 2.000 & 2.000 & 2.000 & 2.000 & 2.000 & 2.000 & 2.000 & 2.000 & 2.000 \\
\hline 0.055 & 0.047 & 0.032 & 0.030 & 0.039 & 0.048 & 0.035 & 0.047 & 0.027 & 0.030 & 0.032 & 0.016 & 0.017 & 0.027 & 0.033 \\
\hline 0.063 & 0.060 & 0.026 & 0.024 & 0.024 & 0.022 & 0.015 & 0.022 & 0.016 & 0.038 & 0.036 & 0.039 & 0.027 & 0.035 & 0.027 \\
\hline 0.728 & 0.751 & 0.857 & 0.875 & 0.871 & 0.868 & 0.937 & 0.884 & 0.903 & 0.793 & 0.824 & 0.812 & 0.868 & 0.855 & 0.861 \\
\hline 0.273 & 0.264 & 0.216 & 0.213 & 0.210 & 0.175 & 0.153 & 0.154 & 0.201 & 0.282 & 0.262 & 0.280 & 0.263 & 0.233 & 0.224 \\
\hline 0.004 & 0.004 & 0.006 & 0.004 & 0.005 & 0.004 & 0.006 & 0.000 & 0.000 & 0.006 & 0.004 & 0.006 & 0.007 & 0.006 & 0.007 \\
\hline 0.843 & 0.863 & 0.839 & 0.833 & 0.823 & 0.852 & 0.822 & 0.863 & 0.845 & 0.834 & 0.820 & 0.829 & 0.789 & 0.836 & 0.845 \\
\hline 0.029 & 0.000 & 0.036 & 0.036 & 0.039 & 0.029 & 0.032 & 0.039 & 0.000 & 0.000 & 0.000 & 0.030 & 0.046 & 0.000 & 0.000 \\
\hline 0.008 & 0.010 & 0.007 & 0.004 & 0.015 & 0.012 & 0.010 & 0.015 & 0.004 & 0.000 & 0.005 & 0.000 & 0.004 & 0.004 & 0.000 \\
\hline 4.004 & 3.999 & 4.019 & 4.020 & 4.025 & 4.011 & 4.009 & 4.024 & 3.996 & 3.982 & 3.982 & 4.012 & 4.012 & 3.996 & 3.997 \\
\hline 39.4 & 39.8 & 44.7 & 45.5 & 45.6 & 45.7 & 48.8 & 46.5 & 46.3 & 41.4 & 43.1 & 42.2 & 45.0 & 44.3 & 44.5 \\
\hline 15.0 & 14.3 & 11.6 & 11.3 & 11.2 & 9.5 & 8.3 & 8.1 & 10.3 & 15.1 & 13.9 & 14.8 & 14.0 & 12.4 & 11.9 \\
\hline 45.6 & 45.9 & 43.7 & 43.3 & 43.1 & 44.8 & 42.9 & 45.4 & 43.4 & 43.5 & 42.9 & 43.0 & 41.0 & 43.3 & 43.6 \\
\hline 87.4 & 88.6 & 93.6 & 94.2 & 92.3 & 91.8 & 94.1 & 91.7 & 96.0 & 96.1 & 96.2 & 94.5 & 95.2 & 94.3 & 94.5 \\
\hline 12.6 & 11.4 & 6.4 & 5.8 & 7.7 & 8.2 & 5.9 & 8.3 & 4.0 & 3.9 & 3.8 & 5.5 & 4.8 & 5.7 & 5.5 \\
\hline 0.727 & 0.740 & 0.799 & 0.804 & 0.806 & 0.832 & 0.859 & 0.852 & 0.818 & 0.738 & 0.759 & 0.744 & 0.768 & 0.786 & 0.793 \\
\hline
\end{tabular}


Table 5. Representative analyses of olivine, Hole 474A, 475B, 477, and 478.

\begin{tabular}{|c|c|c|c|c|c|c|c|c|c|c|c|c|c|c|c|c|c|c|c|c|}
\hline \multirow{2}{*}{\multicolumn{2}{|c|}{ Mineral $\begin{array}{c}\text { Analysis } \\
\text { Number }\end{array}$}} & \multicolumn{6}{|c|}{ Sample $474 \mathrm{~A}-42-2,20-23$} & \multicolumn{4}{|c|}{ Sample 475B-2-1, 0-9 } & \multicolumn{5}{|c|}{ Sample $474 \mathrm{~A}-46-3,80-82$} & \multicolumn{3}{|c|}{ Sample 477-13-2, 145-146 } & \multirow{2}{*}{$\begin{array}{c}\text { Sample 478-42-2, } \\
82-83\end{array}$} \\
\hline & & Ib & 2 & 3a & $3 \mathrm{~b}$ & 4 & 5 & 6 & 8 & 10 & 11 & 12 & 13 & 14 & 15 & 16 & 18 & 19 & 20 & \\
\hline $\mathrm{SiO}_{2}$ & 40.00 & 40.58 & 39.93 & 40.20 & 39.83 & 40.11 & 40.51 & 39.87 & 40.34 & 40.21 & 40.26 & 39.48 & 40.75 & 40.05 & 40.11 & 40.16 & 39.17 & 40.14 & 39.91 & 38.09 \\
\hline $\mathrm{FeO}$ & 11.30 & 11.67 & 11.64 & 11.57 & 11.57 & 11.62 & 11.22 & 11.99 & 11.25 & 12.21 & 11.43 & 14.20 & 11.25 & 13.28 & 14.28 & 13.76 & 15.53 & 15.27 & 15.32 & 26.00 \\
\hline $\mathrm{MnO}$ & 0.13 & 0.16 & 0.18 & 0.12 & 0.20 & 0.17 & - & 0.18 & 0.15 & 0.15 & - & 0.18 & 0.15 & 0.17 & 0.15 & 0.17 & 0.15 & 0.24 & 0.26 & 0.41 \\
\hline $\mathrm{MgO}$ & 46.49 & 46.85 & 46.71 & 46.98 & 46.82 & 46.82 & 46.88 & 45.71 & 47.00 & 45.44 & 46.70 & 44.69 & 47.09 & 44.51 & 45.54 & 45.01 & 43.89 & 44.27 & 43.90 & 35.18 \\
\hline $\mathrm{CaO}$ & 0.27 & 0.27 & 0.26 & 0.38 & 0.35 & 0.24 & 0.37 & 0.37 & 0.39 & 0.33 & 0.39 & 0.38 & 0.39 & 0.40 & 0.39 & 0.35 & 0.37 & 0.38 & 0.35 & 0.29 \\
\hline $\mathrm{NiO}$ & 0.17 & 0.22 & 0.27 & 0.22 & 0.27 & 0.30 & 0.32 & 0.27 & 0.24 & 0.23 & 0.15 & - & 0.23 & 0.21 & 0.16 & 0.21 & - & - & 0.16 & - \\
\hline Total & 98.34 & 99.75 & 98.99 & 99.46 & 99.04 & 99.27 & 99.29 & 98.38 & 99.35 & 98.56 & 98.92 & 99.81 & 99.86 & 98.61 & 100.63 & 99.67 & 99.12 & 100.34 & 99.90 & 100.20 \\
\hline \multicolumn{21}{|c|}{ Cations Based on 4 Oxygens } \\
\hline $\mathrm{Si}$ & 1.005 & 1.006 & 0.999 & 1.000 & 0.997 & 1.001 & 1.007 & 1.001 & 1.002 & 1.012 & 1.002 & 1.000 & 1.007 & 1.012 & 0.998 & 1.006 & 0.996 & 1.003 & 1.005 & 1.006 \\
\hline $\mathrm{Fe}$ & 0.237 & 0.242 & 0.244 & 0.241 & 0.242 & 0.242 & 0.233 & 0.252 & 0.234 & 0.257 & 0.238 & 0.301 & 0.233 & 0.281 & 0.297 & 0.288 & 0.330 & 0.319 & 0.323 & 0.575 \\
\hline $\mathrm{Mn}$ & 0.003 & 0.004 & 0.004 & 0.002 & 0.004 & 0.004 & - & 0.004 & 0.003 & 0.003 & - & 0.004 & 0.003 & 0.004 & 0.003 & 0.004 & 0.003 & 0.005 & 0.006 & 0.009 \\
\hline $\mathrm{Mn}$ & 1.740 & 1.731 & 1.742 & 1.742 & 1.746 & 1.740 & 1.737 & 1.710 & 1.740 & 1.703 & 1.733 & 1.686 & 1.735 & 1.676 & 1.689 & 1.681 & 1.664 & 1.649 & 1.648 & 1.385 \\
\hline $\mathrm{Ca}$ & 0.007 & 0.007 & 0.007 & 0.010 & 0.009 & 0.006 & 0.010 & 0.010 & 0.010 & 0.009 & 0.010 & 0.010 & 0.010 & 0.011 & 0.010 & 0.009 & 0.010 & 0.010 & 0.009 & 0.008 \\
\hline $\mathrm{Ni}$ & 0.003 & 0.004 & 0.005 & 0.004 & 0.005 & 0.006 & 0.006 & 0.005 & 0.005 & 0.005 & 0.003 & - & 0.005 & 0.004 & 0.003 & 0.004 & - & - & 0.003 & - \\
\hline Total & 2.995 & 2.994 & 3.001 & 3,000 & 3.003 & 2.999 & 2.993 & 2.981 & 2.995 & 2.988 & 2.986 & 3.000 & 2.993 & 2.988 & 3.002 & 2.993 & 3.004 & 2.986 & 2.995 & 2.990 \\
\hline Fo & 88.0 & 87.7 & 87.7 & 87.9 & 87.8 & 87.7 & 88.2 & 87.2 & 88.2 & 86.9 & 87.9 & 84.9 & 88.2 & 85.7 & 85.0 & 85.4 & 83.4 & 83.8 & 83.6 & 70.7 \\
\hline
\end{tabular}

Note: All Fe as FeO; blank means not detected. 1a-1b, core and rim of microphenocryst; 2 , core of microphenocryst; 3a-3b, core and rim of phenocrysts; 4 , 5 , interiors of phenocrysts; 6,8 , microphenocrysts; 10 , 11, phenocrysts; $12,14,15$ microphenocrysts; 13,16 phenocrysts; 18,20 microphenocrysts, 19 phenocryst; 22 small anhedral phenocryst.

Table 6. Representative analyses of iron-titanium oxides, Holes 474A and 478 .

\begin{tabular}{|c|c|c|c|c|c|c|c|c|}
\hline \multirow{2}{*}{$\begin{array}{l}\text { Analysis } \\
\text { Number }\end{array}$} & \multicolumn{3}{|c|}{$\begin{array}{c}\text { Sample } 474 \mathrm{~A}-40-2 \text {, } \\
\quad 38-40\end{array}$} & \multicolumn{2}{|c|}{$\begin{array}{c}\text { Sample } 474 \mathrm{~A} \text {. } \\
45-4, \\
45-4,7-9\end{array}$} & \multicolumn{3}{|c|}{$\begin{array}{c}\text { Sample 478-51-3, } \\
52-53\end{array}$} \\
\hline & 1 & 2 & 3 & 5 & 6 & 7 & 8 & 9 \\
\hline $\mathrm{SiO}_{2}$ & 1.10 & 1.42 & 0.81 & 2.39 & 2.62 & 0.69 & 0.64 & 0.70 \\
\hline $\mathrm{Al}_{2} \mathrm{O}_{3}$ & 2.28 & 2.17 & 1.94 & 2.42 & 1.97 & 0.85 & 0.00 & 2.06 \\
\hline $\mathrm{TiO}_{2}$ & 24.97 & 25.95 & 25.71 & 20.36 & 22.56 & 18.01 & S0.02 & 18.34 \\
\hline $\mathrm{Fe}_{2} \mathrm{O}_{3}$ & 16.30 & 13.45 & 15.82 & 18.28 & 16.00 & 31.28 & 6.31 & 29.18 \\
\hline $\mathrm{FeO}$ & 51.91 & 52.86 & 52.84 & 50.94 & 54.31 & 45.62 & 38.46 & 44.68 \\
\hline $\mathrm{MgO}$ & 2.28 & 2.06 & 1.89 & 0.41 & 0.36 & 1.46 & 3.66 & 2.55 \\
\hline $\mathrm{MnO}$ & 0.63 & 1.14 & 0.64 & 0.50 & 0.47 & 0.56 & 0.62 & 0.52 \\
\hline $\mathrm{CaO}$ & 0.12 & 0.15 & 0.00 & 0.18 & 0.15 & 0.10 & 0.10 & 0.00 \\
\hline $\mathrm{v}_{2} \mathrm{O}_{3}$ & 0.70 & 0.60 & 0.49 & 0.48 & 0.59 & 0.52 & 0.30 & 1.16 \\
\hline Total & 100.29 & 99.80 & 100.14 & 95.96 & 99.03 & 99.09 & 100.11 & 99.19 \\
\hline \multirow[t]{2}{*}{ \%Ulv. } & 70.8 & 74.8 & 72.6 & 64.3 & 69.6 & 52.0 & 88.3 & 52.1 \\
\hline & \multicolumn{8}{|c|}{ Cations Based on 32 Oxygens } \\
\hline SI & 0.319 & 0.413 & 0.236 & 0.730 & 0.777 & 0.207 & $0.126^{\mathrm{a}}$ & 0.206 \\
\hline Al & 0.778 & 0.744 & 0.667 & 0.872 & 0.688 & 0.300 & 0.000 & 0.716 \\
\hline $\mathrm{Ti}_{3}$ & 5,438 & 5.676 & 5.639 & 4.679 & 5.030 & 4.058 & 7.385 & 4.065 \\
\hline $\mathrm{Fe}_{2}^{3}$ & 3.552 & 2.944 & 3.472 & 4.204 & 3.570 & 7.052 & 0.932 & 6.472 \\
\hline $\mathrm{Fe}^{2}$ & 12.572 & 12.859 & 12.889 & 13.018 & 13.465 & 11.430 & 6.315 & 11.014 \\
\hline $\mathrm{Mg}$ & 0.984 & 0.893 & 0.882 & 0.187 & 0.159 & 0.652 & 1.070 & 1.120 \\
\hline $\mathrm{Mn}$ & 0.155 & 0.281 & 0.158 & 0.129 & 0.118 & 0.142 & 0.103 & 0.130 \\
\hline $\mathrm{Ca}$ & 0.037 & 0.047 & 0.000 & 0.059 & 0.048 & 0.032 & 0.021 & 0.000 \\
\hline v & 0.163 & 0.140 & 0.115 & 0.118 & 0.140 & 0.125 & 0.047 & 0.274 \\
\hline Total & 24.00 & 24.00 & 24.00 & 24.00 & 24.00 & 24.00 & 16.00 & 24.00 \\
\hline
\end{tabular}

Note: $\mathrm{Fe}_{2} \mathrm{O}_{3}$ calculated on the basis of ideal spinel stoichiometry: 1-3, subhedral intersertal; 5-6, groundmass crystals: 7-9 groundmass grains.

a Based on 24 oxygens.

scent. Certainly, the inhomogeneous distribution of phenocrysts and the presence of plagioclase xenocrysts in some samples (i.e., high $\mathrm{Al}_{2} \mathrm{O}_{3}$ basalts in Sample 474A-47-1, $101 \mathrm{~cm}$ ) complicate these simple models. Although Units 1 and $2 a$ can be related by fractional crystallization, no combination of mineral extracts from these basalts yielded reasonable solutions for deriving the more fractionated basalts in the underlying units-a point that supports the hypothesis of at least two distinct magma batches at this site.

\section{Hole 475B}

Least-squares fractionation calculations for Hole 475 basalts indicate that the samples could be related to a single parental magma (Sample 475B-4-1, $2 \mathrm{~cm}$ ) by Plag $+\mathrm{Ol}+\mathrm{Cpx}$ fractionation (see Models 18-20, Table 8 ). The percentages of derivative liquid remaining after fractional crystallization are reasonable $(74-86 \%)$ and the residuals are small $\left(\Sigma r^{2}<0.08\right)$ in Models 18 and 20. In these models, olivine must become more fayalitic and
Table 7. Representative spinel analyses from Hole 474A.

\begin{tabular}{|c|c|c|c|}
\hline \multirow[b]{2}{*}{ Mineral } & \multicolumn{3}{|c|}{ Sample $474 \mathrm{~A}-42-2,20-23$} \\
\hline & 1 & 2 & 3 \\
\hline $\mathrm{SiO}_{2}$ & 0.67 & 3.73 & 0.87 \\
\hline $\mathrm{TiO}_{2}$ & 0.29 & 0.65 & 0.34 \\
\hline $\mathrm{Al}_{2} \mathrm{O}_{3}$ & 40.23 & 34.82 & 42.37 \\
\hline $\mathrm{V}_{2} \mathrm{O}_{3}$ & 0.14 & 0.17 & 0.13 \\
\hline $\mathrm{Cr}_{2} \mathrm{O}_{3}$ & 25.85 & 23.55 & 21.97 \\
\hline $\mathrm{Fe}_{2} \mathrm{O}_{3}$ & 2.44 & 2.00 & 3.34 \\
\hline $\mathrm{FeO}$ & 11.58 & 16.62 & 12.25 \\
\hline $\mathrm{Mg}$ & 17.90 & 15.99 & 17.85 \\
\hline $\mathrm{MnO}$ & 0.14 & 0.29 & 0.26 \\
\hline $\mathrm{CaO}$ & 0.16 & 0.95 & 0.11 \\
\hline $\mathrm{NiO}$ & 0.26 & 0.18 & 0.18 \\
\hline Total & 99.66 & 98.95 & 99.67 \\
\hline $\begin{array}{l}\mathrm{Cr} / \mathrm{Cr}+\mathrm{Al} \\
\mathrm{Mg} / \mathrm{Mg}+\mathrm{Fe}^{2}\end{array}$ & $\begin{array}{l}0.301 \\
0.734\end{array}$ & $\begin{array}{l}0.312 \\
0.632\end{array}$ & $\begin{array}{l}0.258 \\
0.723\end{array}$ \\
\hline $\mathrm{Fe}^{3} / \mathrm{Cr}+\mathrm{Al}+\mathrm{Fe}^{3}$ & 0.026 & 0.025 & 0.036 \\
\hline
\end{tabular}

Note: 1 , groundmass euhedral grain; $2-3$, subhedral inclusions in olivine. $\mathrm{Fe}_{2} \mathrm{O}_{3}$ calculated assuming ideal spinel stoichiometry.

plagioclase more albitic as fractionation proceeds. The absence, as in the holes already mentioned, of modal plagioclase and clinopyroxene, however, is problematic. Only 5-10\% Ol with traces of spinel exists in these glassy basalts, yet significant amounts of Plag and Cpx fractionation are predicted to explain the major-element variations at this site. Furthermore, the relatively constant $\mathrm{Ni}, \mathrm{Cr}$, and incompatible trace-element contents in these samples suggest that little crystallization of $\mathrm{Ol}$ or $\mathrm{Cpx}$ could have occurred.

\section{Holes 477 and 477A}

Results of the fractionation calculations for basalts from the Guaymas Basin are presented in Table 9. In general, the dolerites from Hole 477 are plagioclase-rich with correspondingly high $\mathrm{Al}_{2} \mathrm{O}_{3}$ and $\mathrm{Sr}$ contents (see Fig. 1). On the basis of trace-element abundances, Saunders et al. (this volume) have suggested that Units $2 b$ 


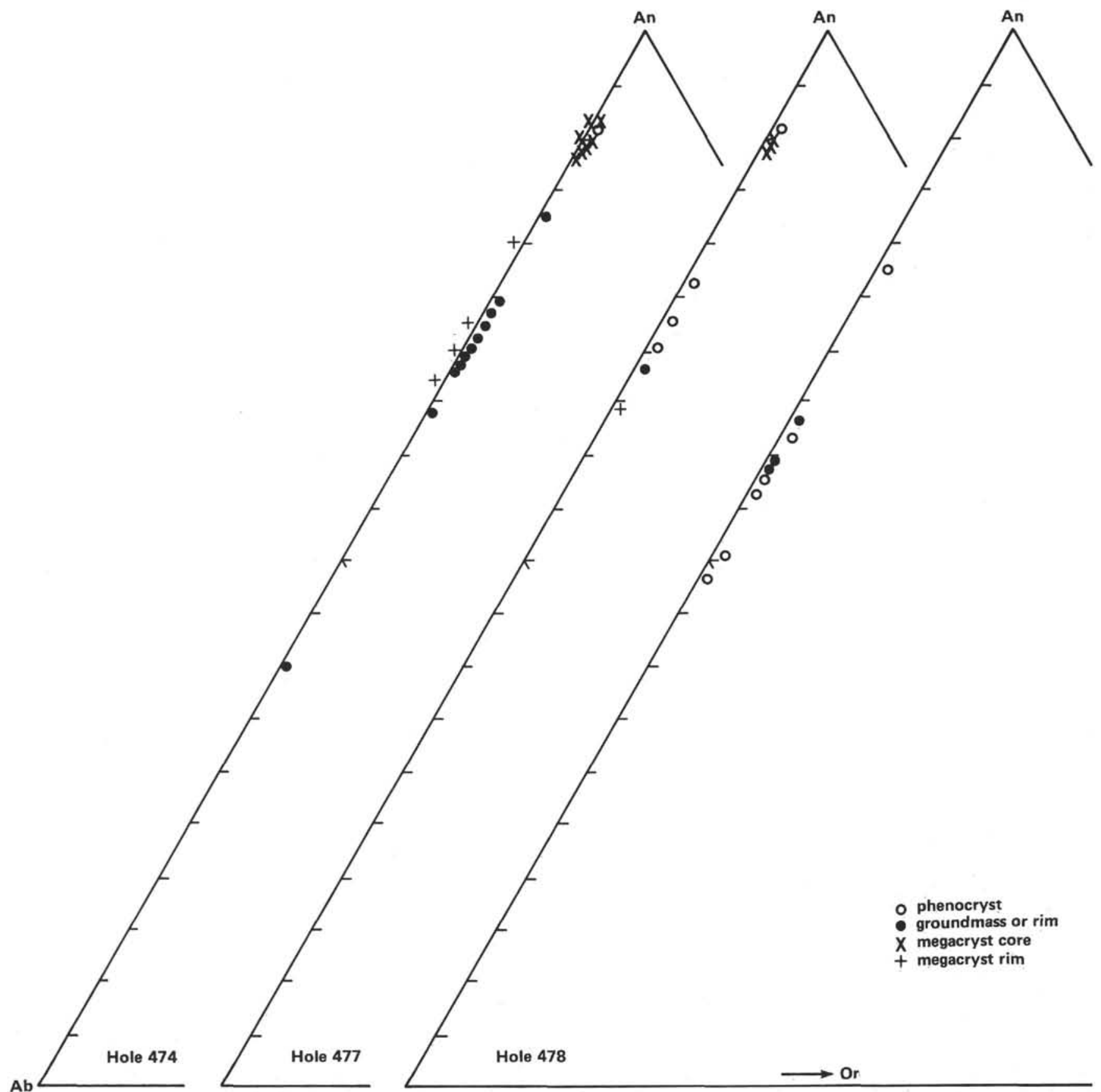

Figure 4. Ternary plot of Or-Ab-An end members for plagioclases in basalts, Holes 474, 477, and 478. (Open symbols represent phenocrysts; closed symbols represent groundmass or rim compositions. Note that megacryst [often xenocrysts] rims and cores are also plotted.)

and $2 \mathrm{c}$ could have been derived from the same parental magma by low-pressure fractional crystallization of approximately $30 \% \mathrm{Plag}+\mathrm{Ol}$. Our calculations indicate that the removal of $11.5 \mathrm{wt} . \% \mathrm{Ol}$ and $15.3 \mathrm{wt} . \%$ Plag from a magma with the composition of Sample 477-12$4,76 \mathrm{~cm}$ (Mg number: 68.32 ) would result in $72.3 \%$ liquid with a composition like that in Sample 477-9-1, 57 $\mathrm{cm}$ (Model 3, Table 9). Slight intraunit variations can also be explained by $\mathrm{Ol}+\mathrm{Plag} \pm \mathrm{Cpx}$ fractionation (see Models 1, 2, 4, 5). The addition of small percentages of $\mathrm{Cpx}$ as a fractionating phase improves the least-squares fit (compare Models 1 and 2, 4 and 5).
In Hole 477A, olivine (5\%) and plagioclase (5\%) appear to be the only liquidus phases in the quenched upper chill zone, but plagioclase and clinopyroxene with lesser olivine are the predominant modal phases downhole, as the basalt changes to dolerite and gabbro. The high $\mathrm{Al}_{2} \mathrm{O}_{3}$ contents almost certainly reflect the high modal plagioclase abundance, and a slight positive europium anomaly in one sample (Saunders et al., this volume) suggests plagioclase accumulation.

Chemical data strongly suggest that the units from Holes 477 and 477A could have been derived from a common parental magma involving varying degrees of 


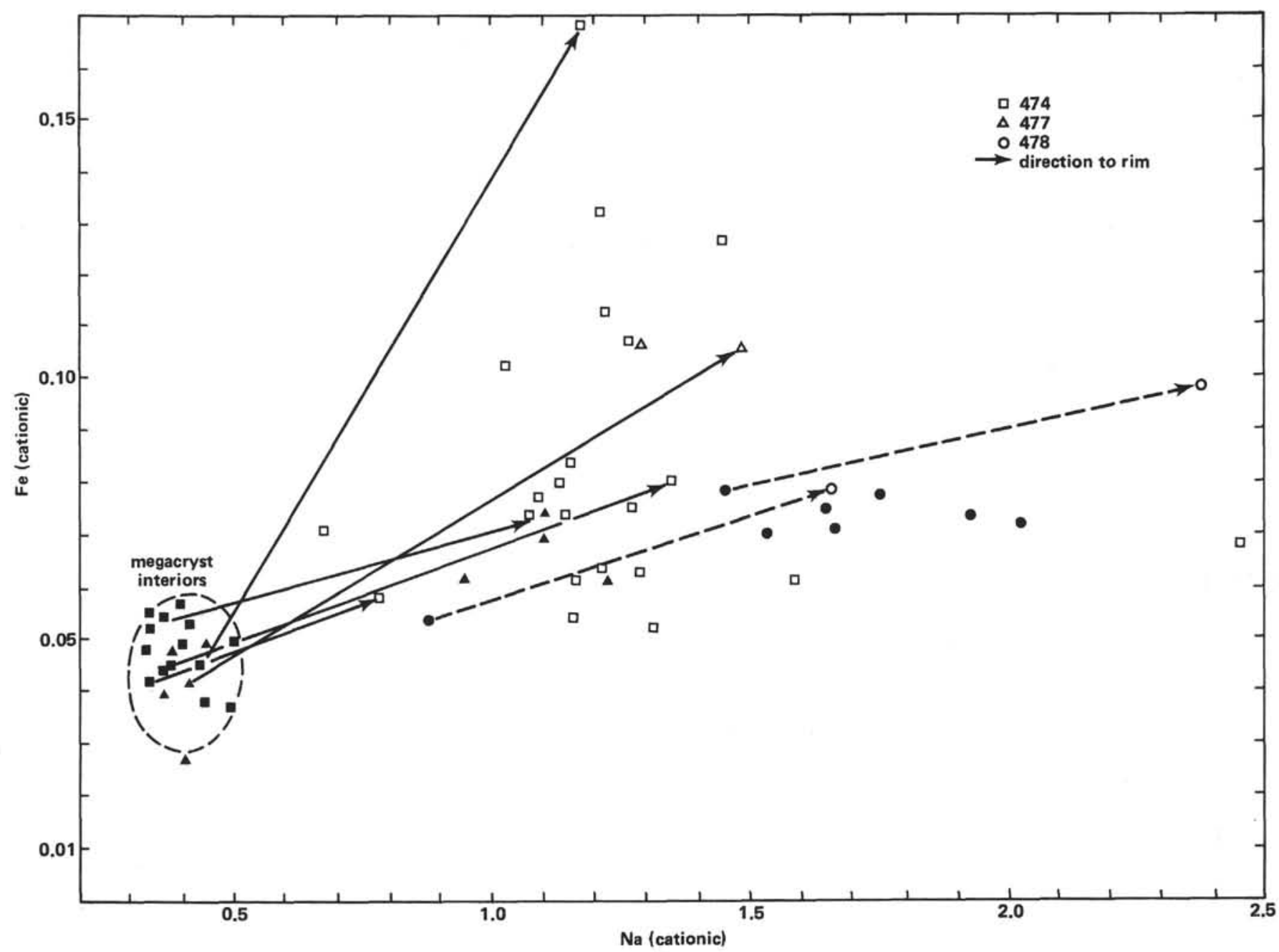

Figure 5. Plot of molecular abundance of Fe versus Na (based on 32 oxygens) for plagioclases, Sites 474, 477, and 478. (Phenocryst and megacryst cores and interior portions are indicated by solid symbols. Rims and groundmass plagioclase are open symbols. Solid lines connect individual cores and rims of megacrysts. Dashed lines connect cores and rims of phenocrysts.)

$\mathrm{Ol}+$ Plag fractionation (Saunders et al., this volume). Model 7 indicates that $\mathrm{Ol}+\mathrm{Plag}(1: 1)$ fractionation is a viable mechanism, but Model 8 shows that the removal of nearly equal percentages of $\mathrm{Cpx}+\mathrm{Ol}+\mathrm{Plag}$ gives a better result. The derivation of high-alumina basalts in Hole 477A also requires $\mathrm{Cpx}+\mathrm{Ol}+\mathrm{Plag}$ fractionation (Model 10). An even better fit, however, is obtained in Model 11 by removing $\mathrm{Ol} \pm \mathrm{Cpx}$ from parental basalt Sample 477A-12-4, $76 \mathrm{~cm}$ and accumulating a small amount $(5.47 \mathrm{wt} . \%)$ of plagioclase in the derivative liquid to produce high-alumina basalt in Sample 477A-3$21,17 \mathrm{~cm}$.

The need to include clinopyroxene as a fractionating phase in the differentiation scheme at Hole 477 is similar to that in the holes previously discussed. Perhaps the best evidence for the involvement of clinopyroxenes is the presence of clinopyroxene phenocrysts in some of the coarser-grained rocks in Hole 477 and the clinopyroxene-rich gabbroic regions observed in Hole 477A. Decreasing $\mathrm{CaO} / \mathrm{Al}_{2} \mathrm{O}_{3}$ ratios with differentiation clearly imply that clinopyroxene may have been removed; but in cases where plagioclase addition has also oc- curred, a similar decrease will also occur (see Fig. 3 and Sample 13-2, $17 \mathrm{~cm}$ ).

\section{Hole 478}

Constant incompatible element ratios and similar chemical compositions of basalts from Units 4, 5, and 6 suggest that these intrusives are consanguineous (Saunders et al., this volume). The most successful calculations indicate that $\mathrm{Cpx}+\mathrm{Plag}+\mathrm{Ol}$ could be fractionated from mafic basalts $(\mathrm{Mg}$ numbers $\sim 69)$ in relatively constant weight proportions ( $\mathrm{Cpx}: \mathrm{Plag}: \mathrm{Ol}=2: 8: 3$ ) to generate the differentiated basalts in Units 4 through 6 . As in previous models, better results (lower $\Sigma r^{2}$ ) were obtained with a three-phase assemblage rather than with only $\mathrm{Ol}+\mathrm{Plag}$ (compare Models 16 and 17). When clinopyroxene is involved, however, relatively greater percentages of crystals $(>50 \%)$ must be removed, and the compositions of plagioclase and olivine are unlike observed phenocryst compositions. Therefore, low-pressure crystallization of $\mathrm{Ol}+\mathrm{Plag}$ may be more realistic in this case. 


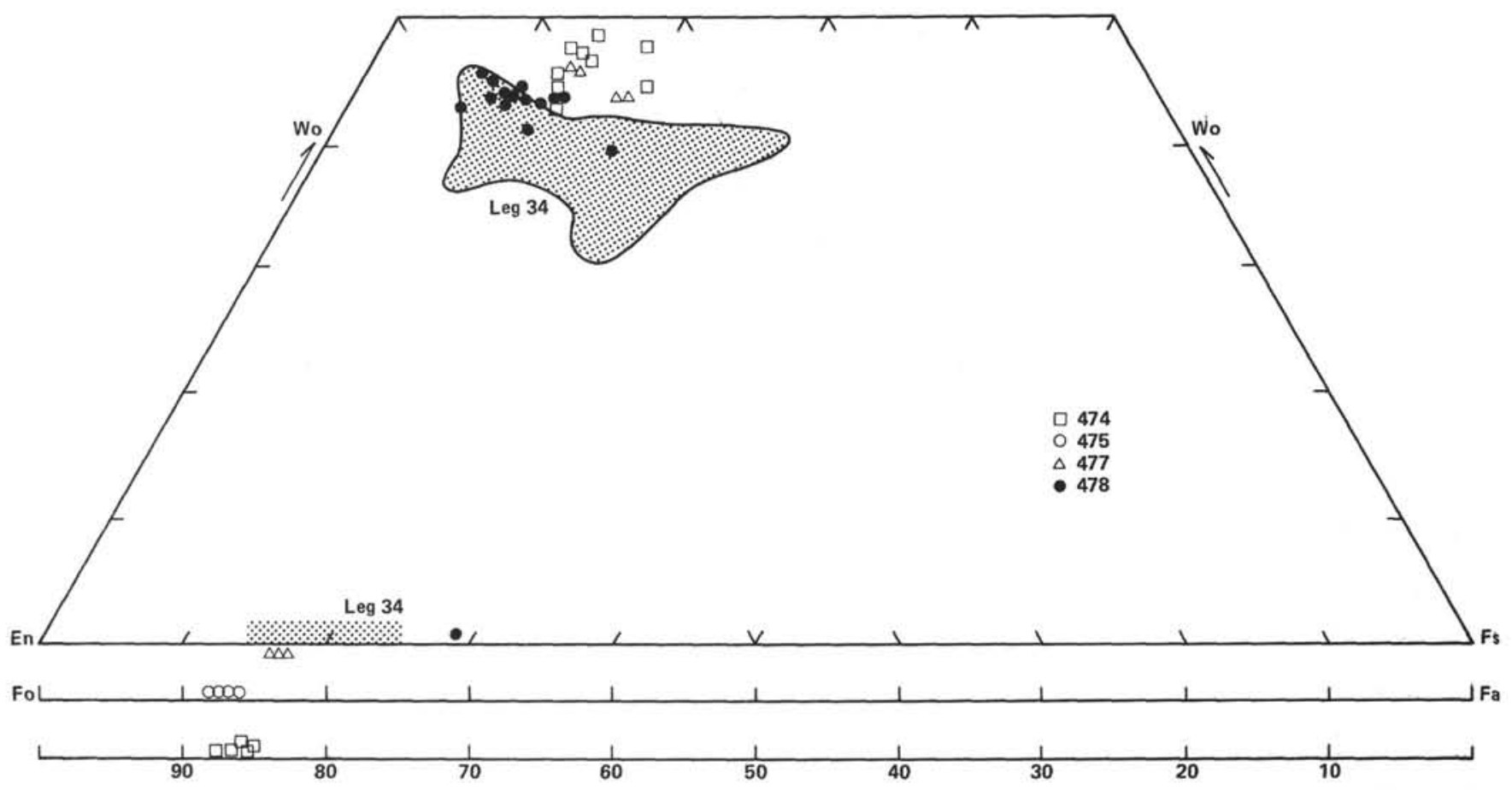

Figure 6. Pyroxene analyses (see Table 4) plotted on the pyroxene quadrilateral (Ca-Mg-Fe $+\mathrm{Mn}$ ). (Olivine compositions [see Table 5] are also plotted on the base of the quadrilateral along the $\mathrm{Mg}-\mathrm{Fe}$ join. Fields [stippled pattern] for pyroxenes in basalts from Leg 34 [Mazzullo and Bence, 1976] are shown for comparison.)

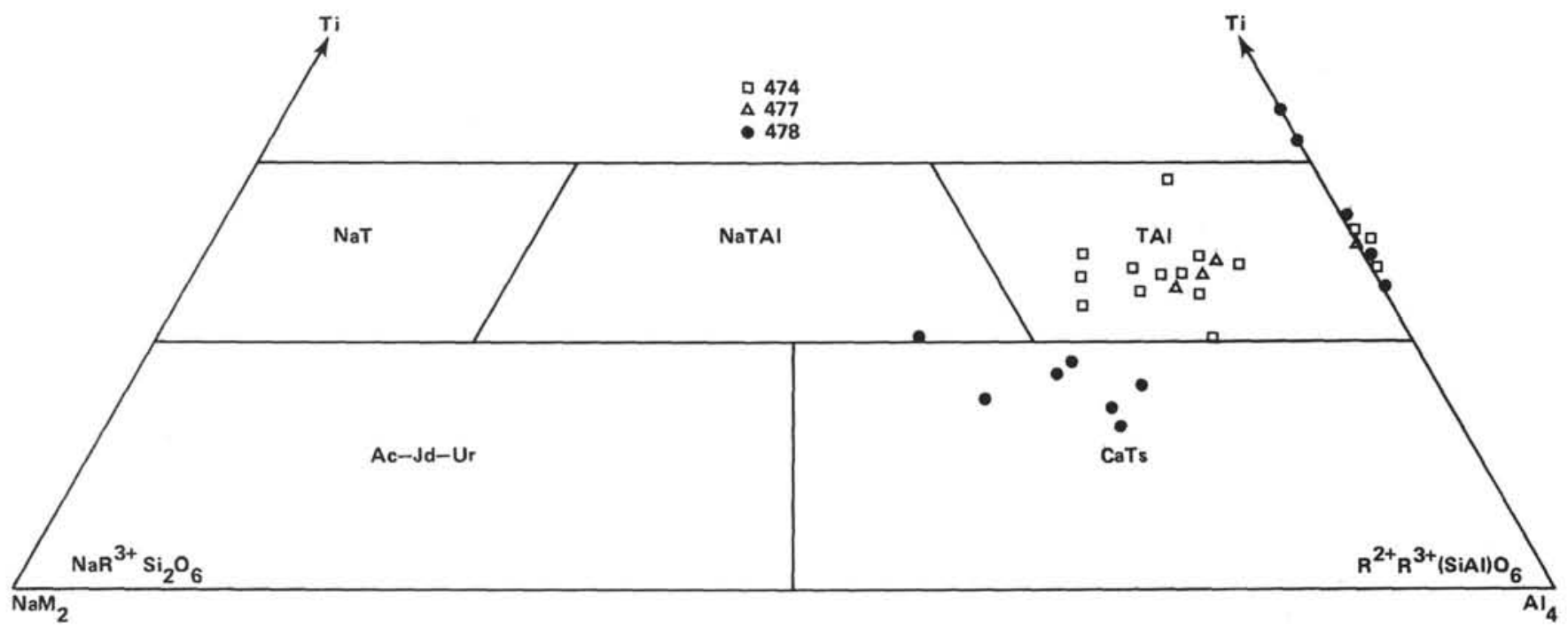

Figure 7. Pyroxene quadrilateral showing “other" components in pyroxenes, Holes 474,477 , and 478.

A xenolith of differentiated gabbro (Sample 478-51$3,49 \mathrm{~cm}$ ) highly enriched in incompatible elements may be derived by extensive fractionation $(66-82 \%)$ of a mafic parent. Low $\mathrm{MgO}, \mathrm{Ni}$, and $\mathrm{Cr}$ contents, high incompatible-element abundances, a negative europium anomaly, and low $\mathrm{Ti} / \mathrm{Zr}$ ratios led Saunders et al. (this volume) to suggest removal of $\mathrm{Ol}+\mathrm{Cpx}+\mathrm{Plag}+\mathrm{il}-$ menite \pm titanomagnetite from a melt at the top of a subridge magma chamber to produce the composition of the xenolith. Model 15 (Table 9) supports this but indicates that $>80 \%$ of the original magma would have had to crystallize. Such extensive crystallization would severely deplete residual liquids in $\mathrm{Ni}$ and $\mathrm{Cr}$ and cause four- to tenfold enrichments in incompatible elements. With the deletion of titanomagnetite as a fractionating phase, the fit is not as good, but the percentages of residual liquids $(\sim 33 \%)$ are in better agreement with the observed trace-element abundances in the gabbro.

As was found for Hole 477, there is some petrographic evidence that support Cpx extraction in Hole 478. Clinopyroxene and plagioclase are cumulate phases in some of the coarse-grained rocks of Cores 42 and 


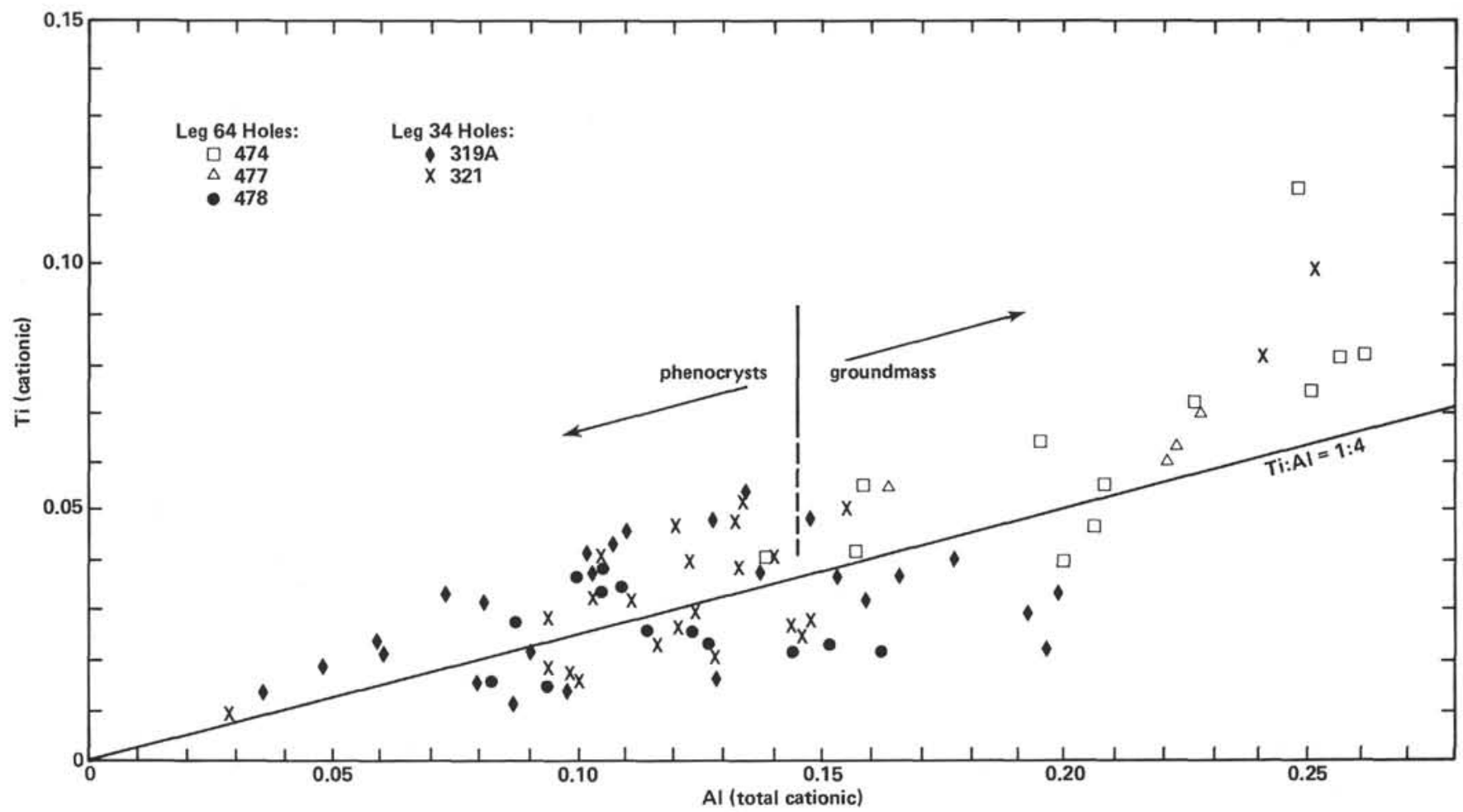

Figure 8. Plot of molecular Ti versus Al (total) in pyroxenes. (Substitutional trend of $1 \mathrm{Ti}: 4 \mathrm{Al}$ molecules is shown. Generalized fields of phenocrysts and groundmass pyroxenes are defined. Analyses of pyroxenes from Leg 34 [Holes 319A and 321; Mazzullo and Bence, 1976] are plotted for comparison to pyroxenes from Leg 64.)

43, and clinopyroxene may be enclosed in plagioclase, which suggests it was a near-liquidus phase. In general, olivine comprises only a small modal percentage of these basalts $(5 \%)$, whereas clinopyroxene may constitute 20 to $50 \%$ of the mode.

\section{Hole 481A}

The suite of basalts recovered from Hole 481A is, as a whole, the most evolved in the Guaymas Basin. The samples have low $\mathrm{Al}_{2} \mathrm{O}_{3}$ contents (Fig. 1) and most show a negative correlation between $\mathrm{CaO} / \mathrm{Al}_{2} \mathrm{O}_{3}$ and $\mathrm{Mg}$ number (Fig. 3). As in Holes 477 and 478, the basalts are transitional from glassy and vitrophyric to doleritic and gabbroic in the centers of intrusive units. The most evolved sample is a gabbro (Sample 481A-15-3, $115 \mathrm{~cm}$ ) in the center of a subunit.

Fractionation models stress the dominance of $\mathrm{Cpx}+$ Plag fractionation in Unit 1 (Models 21-23, Table 9). Little variation in $\mathrm{Ni}$ abundances with increasing $\mathrm{Zr}$ contents suggests that olivine fractionation was not significant during differentiation (Saunders et al., this volume). Our calculations confirm this suggestion. However, in deriving low $\mathrm{MgO}$ basalt (Sample 481-33-1, 91 $\mathrm{cm}$ ) in Unit 3 from a more mafic parent, such as Sample $481-17-2,6 \mathrm{~cm}$ ) in Unit 1, 9.6\% Plag $+6.3 \% \mathrm{Ol}$, and only minor Cpx $(0.3 \%)$ need be removed (Model 24, Table 9). This scheme explains the low $\mathrm{Ni}$ and high $\mathrm{CaO} / \mathrm{Al}_{2} \mathrm{O}_{3}$ ratio in the residual liquid.

\section{Intersite Relations}

It is likely that the mantle sources for basalts at Sites 478 and 481 are chemically distinct from the source of basalts at Site 477 (Saunders et al., this volume). Models 25 and 26 (Table 9) suggest that it is possible to derive basalts from Hole 481A (Samples 481A-15-3, $27 \mathrm{~cm}$, $481 \mathrm{~A}-17-2,6 \mathrm{~cm})$ by $\sim 60 \%$ fractional crystallization of a parental magma with the composition of Sample 478$49-1,63 \mathrm{~cm}$. As within each hole, plagioclase dominates the fractionated assemblage, and $\mathrm{Ol}+\mathrm{Cpx}$ are removed in near-equal amounts.

\section{DISCUSSION}

Major-element, trace-element, and mineralogic data from basalts drilled during Leg 64 indicate that a wide chemical variety of $\mathrm{N}$-type MORB has been erupted in the Gulf of California. In particular, the Leg 64 basalts have chemical and mineralogical characteristics broadly similar to those from the East Pacific Rise and the Nazca Plate, although they are not nearly so evolved as many of the basalts from the Galapagos Spreading Center (see Mazzullo and Bence, 1976; Clague and Bunch, 1976; Byerly, 1980; Perfit et al., 1980; Saunders et al., this volume).

The trace-element data indicate that a number of distinct N-type mantle sources or a fairly heterogeneous mantle was partially melted to generate the spectrum of basalts recovered during Leg 64 . Regular variations in both major- and trace-element abundances with increased fractionation appear to be a consequence of closed-system fractional crystallization. Although the least-squares models we have presented generally support this assumption, close examination of the mathematical results with respect to the phase relations in the samples, experimental data on MORB crystallization, 

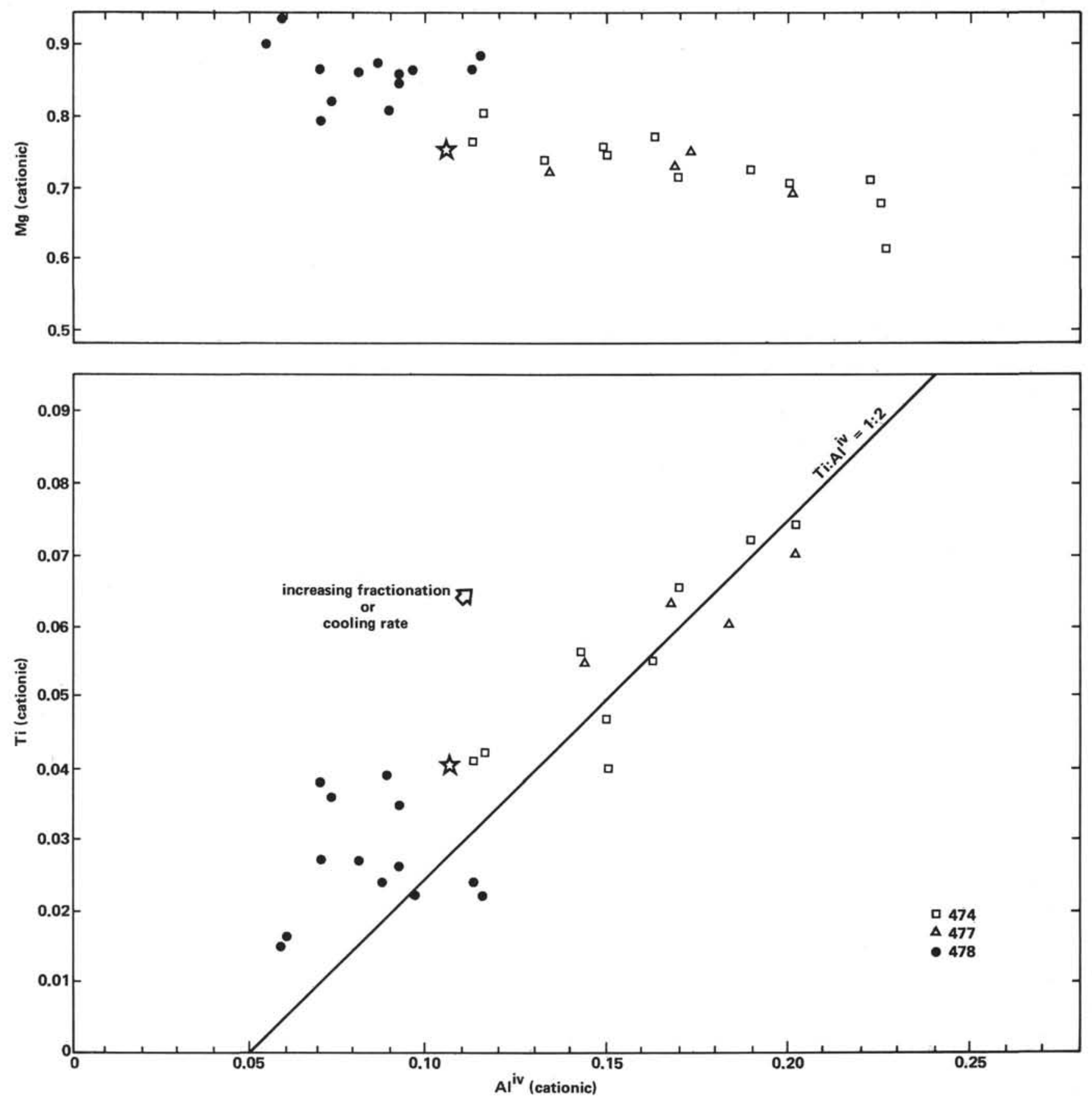

Figure 9. Plot of $\mathrm{Mg}$ and $\mathrm{Ti}$ versus calculated $\mathrm{Al}^{\mathrm{iv}}$ in Leg 64 pyroxenes. (Ti- $\mathrm{Al}^{\mathrm{iv}}$ [1:2] increases resulting from increased fractionation or increased cooling rate are diagrammatically shown. Stars represent the average composition of Leg 34 pyroxenes [Schweitzer et al., 1979].)

and predicted trace-element variations clearly indicate that in most cases simple closed-system crystal fractionation does not adequately explain all of the observed chemical and mineralogical features. In particular, it fails to explain (1) the common presence of Anrich plagioclase xenocrysts, (2) the inhomogeneous distribution of olivine and/or plagioclase in some units, (3) the presence of aluminous spinel in a few mafic samples, (4) the excessive enrichments of incompatible elements (e.g., $\mathrm{Ti}, \mathrm{Zr}, \mathrm{P}$ ), and relatively small decreases in $\mathrm{Ni}$ and $\mathrm{Cr}$ in evolved basalts, and (5) the inverse relation between
$\mathrm{CaO} / \mathrm{Al}_{2} \mathrm{O}_{3}$ and $\mathrm{Mg}$ number with little evidence of clinopyroxene fractionation.

Picritic basalts from Hole 474A (Mg numbers 75) could represent the composition of melts derived directly from the mantle (i.e., primary); however, they have noticeable excess concentrations of olivine phenocrysts ( \pm spinel) and therefore may be cumulate. Spinel microphenocrysts in some olivine-rich basalts are an aluminous variety generally associated with picritic MORB. Fisk and Bence (1980) suggest that such spinels could crystallize in magmas enriched in $\mathrm{MgO}$ by the 
Table 8. Least-squares fractionation calculations, Holes 474A, 475B.

\begin{tabular}{|c|c|c|c|c|c|c|c|c|c|}
\hline $\begin{array}{l}\text { Model } \\
\text { Number }\end{array}$ & $\begin{array}{l}\text { Parent } \\
\text { Sample } \\
\text { (level }\end{array}$ & $\begin{array}{l}\text { Derivative } \\
\text { Sample } \\
\text { in } \mathrm{cm} \text { ) }\end{array}$ & Liq & Cpx & PlagAn & $\mathrm{Ol}_{\mathrm{Fo}}$ & Spnl & $\Sigma r^{2}$ & Comments \\
\hline \multicolumn{10}{|l|}{$474 A$} \\
\hline 1 & $42-1,6$ & $40-2,40$ & 86.27 & & & 7.4990 & 7.67 & 0.673 & \\
\hline 2 & $40-2,40$ & $39-3,148$ & 92.22 & & & 9.2790 & & 0.887 & $+\mathrm{FeO}$ \\
\hline 3 & $40-2,40$ & $45-4,64$ & 80.84 & 3.04 & $3.92_{40}$ & 11.390 & & 0.061 & \\
\hline 4 & $46-3,74$ & $45-4,64$ & 84.42 & & 10.4890 & 4.0990 & & 0.677 & $-\mathrm{CaO}$ \\
\hline 5 & $46-3,74$ & $45-4,64$ & 79.47 & 4.75 & 11.2590 & 3.6090 & & 0.172 & $+\mathrm{TiO}_{2},+\mathrm{P}_{2} \mathrm{O}_{5}$ \\
\hline 6 & $46-3,74$ & $50-3,91$ & 71.93 & 6.42 & 17.0190 & 3.9785 & & 0.193 & $+\mathrm{P}_{2} \mathrm{O}_{5}$ \\
\hline 7 & $47-1,127$ & $50-4,1$ & 70.90 & 6.50 & 19.9974 & 3.4785 & & 0.176 & $+\mathrm{TiO}_{2},+\mathrm{K}_{2} \mathrm{O}$ \\
\hline 8 & $47-1,127$ & $50-3,91$ & 66.18 & 7.20 & 22.1075 & 4.8385 & & 0.084 & $+\mathrm{TiO}_{2}$ \\
\hline 9 & $47-1,127$ & $50-3,91$ & 51.01 & 11.47 & 29.9867 & 7.7090 & & 0.039 & \\
\hline 10 & $46-2,112$ & $49-1,2$ & 82.30 & 4.10 & 8.9390 & 4.2385 & & 0.404 & $+\mathrm{TiO}_{2},-\mathrm{FeO}$ \\
\hline 11 & $46-2,112$ & $49 \cdot 2,31$ & 78.96 & 0.70 & 15.0978 & $5.29_{85}^{\circ}$ & & 0.061 & \\
\hline 12 & $46-2,112$ & $45-4,64$ & 87.63 & & 7.8767 & 4.8285 & 1.25 & 0.085 & $+\mathrm{TiO}_{2},-\mathrm{K}_{2} \mathrm{O}$ \\
\hline 13 & $42-1,6$ & $40-1,19$ & 92.99 & 0.25 & 4.3190 & 1.8890 & & 0.160 & $+\mathrm{TiO}_{2},-\mathrm{Na}_{2} \mathrm{O}$ \\
\hline 14 & $42-1,6$ & $40-1,19$ & 86.60 & 5.44 & 4.2940 & 1.5690 & 2.77 & 0.052 & $+\mathrm{TiO}_{2}^{2}$ \\
\hline 15 & $40-1,19$ & $39-3,148$ & 66.53 & & 10.3890 & 20.1790 & & 0.974 & $-\mathrm{TiO}_{2},-\mathrm{FeO},-\mathrm{K}_{2} \mathrm{O}$ \\
\hline 16 & $42-1,6$ & $39-3,148$ & 68.73 & 4.06 & 5.4390 & 16.9690 & 6.08 & 0.108 & $-\mathrm{Na}_{2} \mathrm{O}$ \\
\hline 17 & $48-1,101$ & $50-4,1$ & 81.70 & 6.30 & 10.6490 & 1.4890 & & 0.310 & $+\mathrm{TiO}_{2},+\mathrm{P}_{2} \mathrm{O}_{5},+\mathrm{K}_{2} \mathrm{O}$ \\
\hline \multicolumn{10}{|l|}{ 475B } \\
\hline 18 & $4-1,2$ & 3-1, 2 & 85.88 & 2.49 & 5.3690 & 6.5286 & & 0.048 & \\
\hline 19 & $4-1,2$ & $3-1,2$ & 69.97 & 6.93 & 7.7190 & 14.1676 & & 0.369 & $-\mathrm{Na}_{2} \mathrm{O}_{1}+\mathrm{P}_{2} \mathrm{O}_{5}$ \\
\hline 20 & $4-1,2$ & $2-1,32$ & 73.55 & 8.54 & 8.5473 & 8.0977 & & 0.078 & $-\mathrm{Na}_{2} \mathrm{O}$ \\
\hline 21 & $4-1,2$ & $2-1,32$ & 100.39 & & $-5.77_{40}$ & 4.5590 & & 0.920 & $+\mathrm{TiO}_{2},-\mathrm{CaO}$ \\
\hline
\end{tabular}

Table 9. Least-squares fractionation calculations, Guaymas Basin.

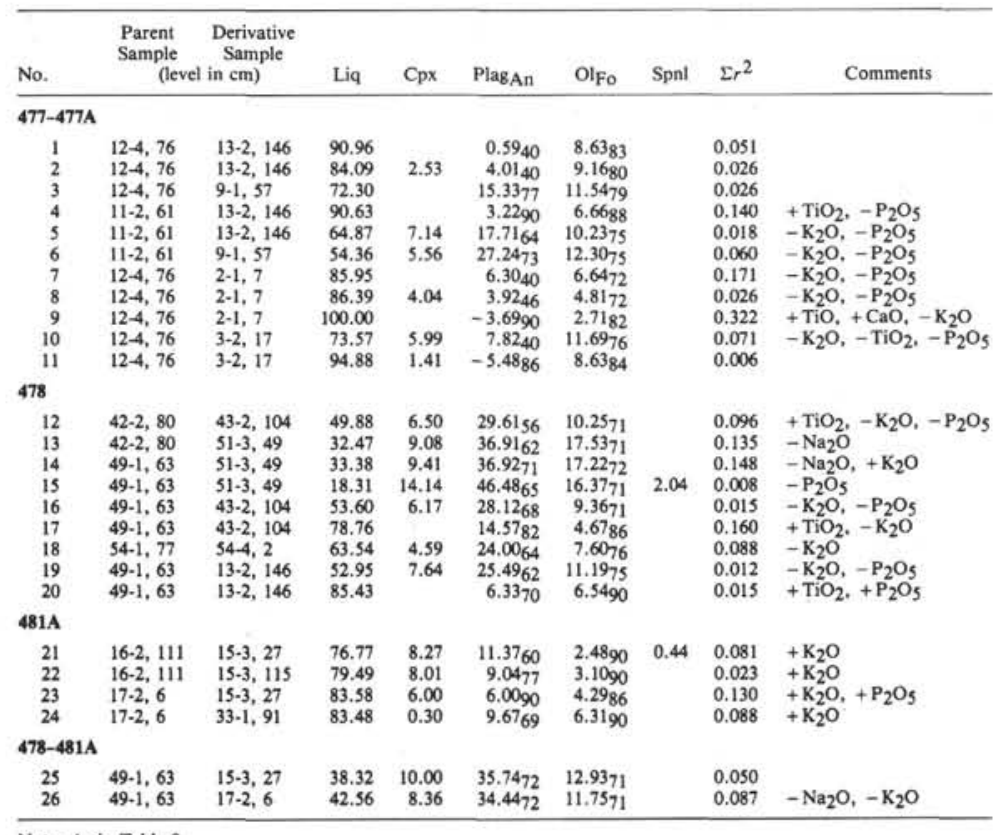

Note: As in Table 8 .

addition of forsteritic olivine. This implies that even though olivine may have accumulated by post-emplacement gravitational settling, spinel could have formed in situ and not have been a fractionating phase. The fact that none of the natural glasses recovered during Leg 64 (Fornari et al., this volume) has compositions as mafic as the picritic basalts is further evidence that such "primary" liquids were not erupted. None of the natural glasses recovered during Leg 64, however, was from a unit with chemistry similar to Units 1 and 2 a from Hole 474A. Consequently, while the chemistry of these units may in part result from cumulus olivine, it is possible that other mechanisms were involved in giving these rocks their unusual depleted trace-element chemistry.
The most primitive, noncumulate basalts from Leg 64 have $\mathrm{Mg}$ numbers $\sim 60$ to 70 and compositions similar to basalts from other ocean-ridge environments that are considered "primitive" MORB (see Dungan and Rhodes, 1978; Bender et al., 1978; Clague and Bunch, 1976). The lack of primary picritic basalts and extreme differentiates may be a consequence of their greater density compared to "primitive" MORB (Sparks et al., 1980; Stolper and Walker, 1980) or result from an efficient magma mixing, which results in an abundance of moderately evolved basalts (Dungan and Rhodes, 1978; Walker et al., 1979). The latter mechanism has great applicability, because it can explain the presence of xenocrysts, the anomalous enrichment of incompatible ele- 
ments, and the major-element variations resulting from cryptic clinopyroxene fractionation.

The presence of An-rich plagioclase xenocrysts that are clearly not in equilibrium with their host basalts suggests that the xenocrysts originally crystallized in more primitive magmas having higher $\mathrm{Ca} / \mathrm{Ca}+\mathrm{Na}$ and $\mathrm{Mg}$ / $\mathrm{Mg}+\mathrm{Fe}$ ratios. Similar arguments, based on $\mathrm{Fe} / \mathrm{Mg}$ equilibration, hold for the forsteritic olivines found in some of the olivine-rich basalts. These features have been used as evidence for the mixing of primitive magmas and their phenocrysts into fractionating magma bodies containing more evolved basalts (Rhodes et al., 1979; Shibata et al., 1979).

One consequence of such magma mixing might be the development of inhomogeneous distributions of phenocrysts within single igneous units, as has occurred in Holes 474 and 477. If the injection of primitive magma occurred at depths greater than $\sim 20 \mathrm{~km}(\sim 6 \mathrm{Kbar})$, then plagioclase $\left(\mathrm{An}_{90}\right)$ would have had a tendency to float in basaltic magmas because of the increased melt density with pressure (see Flower, 1980), whereas olivine would have sunk, eventually producing evolved basalts, rich in plagioclase, and basal picritic basalts such as those sampled in Holes 474 and 477.

Most of the glassy and slightly phyric basalts drilled during Leg 64 contain phenocrysts of plagioclase or olivine, which suggests that they are liquidus phases. This observation conforms to the liquidus phase relations in "primitive" MORB at low pressure (1 atm.; Bender et al., 1978; Walker et al., 1979). Experimental work has also shown that clinopyroxene does not coexist with $\mathrm{Ol}+\mathrm{Plag}$ until $\sim 75-100^{\circ} \mathrm{C}$ below the liquidus, by which time liquids are nearly $50 \%$ crystallized (Bender et al., 1978; Walker et al., 1979).

Many of the fractionation models we present indicate that significant amounts of clinopyroxene must be extracted with $\mathrm{Ol}+$ Plag to adequately explain the observed major-element variations; but this is not compatible with the observed or experimental phase relations. This enigma is encountered in fractionation models derived for other MORB suites (e.g., Clague and Bunch, 1976; Shibata et al., 1979; Byerly, 1980).

The presence of clinopyroxene phenocrysts in relatively few basalts and in a number of gabbros from Leg 64 provides some evidence that crystallization may have been initiated above $\sim 10 \mathrm{Kbar}$, where clinopyroxene is a liquidus phase.

This may explain the origin of cumulate clinopyroxene layers and clinopyroxene-rich gabbros, but the fractionating magmas would have to move to higher levels $(<10 \mathrm{~kb})$ and continue fractionating $\mathrm{Ol}+$ Plag to produce the observed chemical changes. Such a polybaric fractionation scheme, as proposed by Flower (1980), also has the potential to explain the formation of plagioclase-rich differentiates by crystal flotation and accumulation. The lack of clinopyroxene xenocrysts in the Leg 64 basalts does not support this scheme; however, the rather restricted nature of our sampling technique does not completely preclude it.

Magma mixing/fractionation models recently discussed by Dungan and Rhodes (1978), Rhodes et al.
(1979), and Walker et al. (1979) appear to most adequately explain the chemical variations observed in basalts from Leg 64. In particular, mixing primitive and differentiated basalts can produce liquids in which $\mathrm{Cpx}$ (+ Plag) will crystallize before Ol (Walker et al., 1979). This mechanism relies heavily on the development of reasonably evolved basalts (that crystallize Cpx before Ol) by simple crystal fractionation prior to mixing; but if mixing is efficient, no end-members will remain. Linear mixtures of these end-members will produce a liquid composition reflecting the fractionation that previously occurred in the primitive and differentiated melts (Walker et al., 1979). Consequently, least-squares calculations suggesting extensive three-phase fractionation may simply be a consequence of $\mathrm{Ol}+\mathrm{Plag}$ and $\mathrm{Cpx}+$ Plag crystallization prior to the mixing of two evolving liquids. Furthermore, Walker et al. (1979) suggest that subophitic textures-such as those in many of the Leg 64 basalts-may, as a result of mixing, be a consequence of supercooling below the three-phase saturated temperature.

Another important consequence of magma mixing observed in some basalts from Leg 64 is the anomalous enrichment of incompatible elements with little change in compatible element contents. The result of mixing a primitive magma even with small amounts of a highly differentiated liquid is a hybrid magma with incompatible element contents in excess of that predicted by Rayleigh fractionation while continuously buffering compatible elements such as $\mathrm{Cr}$ and $\mathrm{Ni}$ (Dungan and Rhodes, 1978; Rhodes et al., 1979).

To date, the effects of magma mixing and fractional crystallization have been evident only in basalts generated at slow spreading ridges in the Atlantic. The physical and tectonic processes that control such mechanisms exist in areas-such as the Gulf of Californiathat experience more rapid spreading rates.

\section{REFERENCES}

Bence, A. E., Baylis, D. M., Bender, J. F., et al., 1979. Controls on the major and minor element chemistry of mid-ocean ridge basalts and glasses. In Talwani, M., Harrison, C. G., and Hayes, D. E. (Eds.), Deep Drilling Results in the Atlantic Ocean: Ocean Crust: Washington (American Geophysical Union), pp. 331-341.

Bender, J. F., Hodges, F. N., and Bence, A. E., 1978. Petrogenesis of basalts from the Project FAMOUS area: Experimental study from 0-15 kb. Earth Planet. Sci. Lett., 41:277-302.

Byerley, G., 1980. The nature of differentiation trends in some volcanic rocks from the Galapagos spreading center. J. Geophys. Res., 85:3797-3810.

Clague, D. A., and Bunch, T. E., 1976. Formation of ferrobasalts at east Pacific midocean spreading centers. J. Geophys. Res., 81: $4247-4256$

Coish, R. A., and Taylor, L. A., 1979. The effects of cooling rate on texture and pyroxene chemistry in DSDP Leg 34 basalts: A microprobe study. Earth Planet. Sci. Lett., 42:389-398.

Dungan, M. A., and Rhodes, J. M., 1978. Residual glasses and melt inclusions in basalts from DSDP Legs 45 and 46: Evidence for magma mixing. Contrib. Mineral. Petrol., 67:417-431.

Fisk, M. R., and Bence, A. E., 1980. Experimental crystallization of chrome spinel in FAMOUS basalt 527-1-1. Earth Planet. Sci. Lett, , 48:111-123.

Flower, M. F. J., 1980. Accumulation of calcic plagioclase in oceanridge tholeiite: An indication of spreading rate? Nature, 287: 530-532. 
Mazzullo, L. J., and Bence, A. E., 1976. Abyssal tholeiites from DSDP Leg 34: The Nazca Plate. J. Geophys. Res., 81:4237-4351.

Papike, J. J., Cameron, K. L., and Baldwin, K., 1974. Amphiboles and pyroxenes: Characterization of other than quadrilateral components and estimates of ferric iron from microprobe data. Geol. Soc. Am. Abstract with Programs, 6:1053-1054. (Abstract)

Perfit, M. R., Fornari, D. J., Malahoff, A., et al., 1980. Geochemistry and mineralogy of MORB, FETI basalts and andesites from the Galapagos Rift. Trans. Amer. Geophys. Union (EOS), 61: 1143.

Rhodes, J. M., Dungan, M. A., Blanchard, D. P., et al., 1979. Magma mixing at mid-ocean ridges: Evidence from basalts drilled near $22^{\circ} \mathrm{N}$ on the Mid-Atlantic Ridge. Tectonophysics, 55:35-61.

Schweitzer, E. L., Papike, J. J., and Bence, A. E., 1979. Statistical analysis of clinopyroxenes from deep-sea basalts. Am. Mineral., 64:501-513.

Shibata, T., DeLong, S. E., and Walker, D., 1979. Abyssal tholeiites from Oceanographer Fracture Zone I. Petrology and fractionation. Contrib. Mineral. Petrol., 70:89-102.

Sigurdsson, H., and Schilling, J.-G., 1976. Spinels in Mid-Atlantic Ridge basalts: Chemistry and occurrence. Earth Planet. Sci. Lett., 29:7-20.
Sparks, R. S. J., Meyer, P., and Sigurdsson, H., 1980. Density variation amongst mid-ocean ridge basalts: Implications for magma mixing and the scarcity of primitive lavas. Earth Planet. Sci. Lett., 46:419-430.

Statham, P. J., 1976. A comparative study of techniques for quantitative analysis of the X-ray spectra obtained with a $\mathrm{Si}(\mathrm{Li})$ detector. $X$-Ray Spectrom., 5:16-28.

Stopler, E., and Walker, D., 1980. Melt density and the average composition of basalt. Contrib. Mineral. Petrol., 74:7-12.

Sweatman, T. R., and Long, J. V. P., 1969. Quantitative electronprobe microanalysis of rock-forming minerals. J. Petrol., 10: 332-379.

Walker, D., Kirkpatrick, R. J., Longhi, J., et al., 1976. Crystallization history of lunar picritic basalt sample 12002: Phase-equilibria and cooling rate studies. Geol. Soc. Am. Bull., 87:646-656.

Walker, D., Shibata, T., and DeLong, S. E., 1979. Abyssal tholeiites from the Oceanographer Fracture Zone, II. Phase equilibria and mixing. Contrib. Mineral. Petrol., 70:111-125.

Wilkinson, J. F. G., in press. The genesis of mid-ocean ridge basalt. Earth Sci. Rev. 